$\begin{array}{lll}\text { KULTURA } & \text { POLSKA A KADEMIA NAUK } & \text { ISSN 0023-5172 } \\ \text { i } & \begin{array}{l}\text { KOMITET SOCJOLOGII } \\ \text { INSTYTUT STUDIÓW POLITYCZNYCH }\end{array} & \\ \text { SPOLECLENSTWO } & \text { 2009, nr 4 } \quad \text { KULTURA (?) WIZUALNA } & \end{array}$

\author{
BADANIA NAD WIZUALNOŚCIĄ \\ W PERSPEKTYWIE MULTIDYSCYPLINARNEJ. \\ KWESTIONARIUSZ KULTURY WIZUALNEJ
}

\title{
WPROWADZENIE
}

Coraz częściej można usłyszeć, że żyjemy w czasach obrazu. Niedobrze, oczywiście, jeżeli podobne stwierdzenia prowadzą do wrażenia rzekomej nieistotności zjawisk wizualnych w życiu społeczno-kulturowym poprzednich epok albo służą odrzuceniu namysłu nad funkcjami, które nadal pełni język, żeby w ten sposób podkreślić, że kultura ma dziś charakter wyjątkowo wizualny. $\mathrm{W}$ pełni uprawnione wydaje się jednak zwrócenie uwagi na procesy sprawiające, że współczesna kultura wizualna ulega istotnym przekształceniom oraz na związek tych procesów z innymi trendami kulturowymi. Rozwój techniki (skutkujący upowszechnieniem technologii wytwarzania i odtwarzania materiałów wizualnych) czy wzrost znaczenia popkultury (powodujący umasowienie tradycyjnie rozumianych dzieł sztuk wizualnych) znacznie zwiększają liczbę obrazów, które napotykamy w życiu codziennym. Jednocześnie te same procesy wpływają na zmiany jakościowe w sposobach doświadczania przez nas tychże obrazów - technika pozwala na zobaczenie tego, co dotychczas dla oka ludzkiego było niedostępne, popkultura redefiniuje znaczenia tych obrazów, które od dawna można było zobaczyć. To oczywiście tylko wybrane przykłady zjawisk. Ich skutkiem jest jednak dostrzegana konieczność badania obrazów przez coraz większą liczbę dyscyplin i z uwzględnieniem coraz szerszych zakresów tematycznych. W rezultacie mnożą się określenia, które mają definiować zakres specjalizacyjny takich prób. Pojawiają się między nimi i takie, które starają się przekonać nas nie tylko do specyfiki i istotności swojego przedmiotu, ale i do nowego podziału zadań między nauki dotychczas kojarzone $z$ badaniem obrazów.

Pojęciem-wytrychem w tych próbach wydaje się „kultura wizualna” — jako metafora współczesnej rzeczywistości, określenie wizualnego wymiaru praktyk ludzkich, zjawisko społeczne $z$ własną logiką czy mniej lub bardziej zinstytucjonalizowana przestrzeń badań naukowych. Wiele stron poświęcono już na 
zdefiniowanie kontekstów użycia terminu „kultura wizualna” i na ich powiązanie z propozycjami poszczególnym dyscyplin. Być może nawet zbyt wiele, skutkiem czego określenie to niekiedy zaczęło pełnić funkcję fetysza, który przynosi samoistną przyjemność poznawczą, w cieniu pozostawiając badania konkretnych, istniejących obrazów i społecznych aspektów procesów widzenia. Jednym $z$ rezultatów takiego rozłożenia akcentów jest choćby to, że coraz trudniej wyobrazić sobie utworzenie jakiegoś nowego, satysfakcjonującego wielu badaczy przedmiotu wspólnych badań wizualnych. Rozwiązaniem może być propozycja wyjścia od dyskusji multidyscyplinarnej. Takiej dyskusji, w której nie zapomina się o specyfice tradycji poszczególnych dyscyplin oraz o koniecznych i pożądanych różnicach między nimi, a jednocześnie istnieje szansa uświadomienia sobie istnienia rozwiązań i problemów badawczych, które z korzyścią można między tymi dyscyplinami transferować. Wygenerowany w ten sposób nowy punkt widzenia może dać podstawy do dostrzeżenia problemów pozostających dotychczas w cieniu i do pełniejszego ujęcia nowych zjawisk związanych ze społecznym znaczeniem wizualności.

To właśnie chęć sprowokowania takiej dyskusji w polskim kontekście stała za pomysłem Kwestionariusza Kultury Wizualnej. Formuła wystosowania do przedstawicieli różnych dyscyplin tych samych pytań, w odniesieniu do „kultury wizualnej" zastosowana po raz pierwszy przez redaktorów czasopisma „October" ${ }^{1}$, wydała nam się efektywną ramą postulowanej kwerendy podejść. Dokonaliśmy jednak dwóch istotnych zmian w stosunku do angielskiego pierwowzoru. Po pierwsze, zamiast tylko do grona historyków, krytyków i filozofów sztuki, pytania wystosowaliśmy również do przedstawicieli innych dyscyplin. Po drugie, mając świadomość różnic między podejściami różnych nauk, zrezygnowaliśmy $\mathrm{z}$ zawartej $\mathrm{w}$ pierwowzorze prośby o ustosunkowanie się do obiegowych opinii na temat „kultury wizualnej”. Stanęliśmy tym samym przed problemem - w jaki sposób sformułować pytania, żeby zakreślić wspólny obszar dyskusji, nie przekreślając jednocześnie multidyscyplinarnego charakteru projektu przez podporządkowanie go spojrzeniu tylko jednej z nauk. Zdecydowaliśmy się na postawienie pytań bardzo prostych (niekiedy wydają się one nawet banalne). $Z$ jednej strony, gwarantujących wzajemną zrozumiałość, $z$ drugiej natomiast - umożliwiających sondę dotyczącą nie tylko możliwości i ewentualnych korzyści ze wspólnego zainicjowania nowego przedmiotu badań, ale i wspomnianych różnic w obecnych sposobach badania wizualności.

Pierwsze z pytań - Co to jest kultura wizualna? - daje możliwość wyartykułowania wspomnianych odrębności, zdania relacji z już istniejących zapożyczeń oraz uświadomienia przeoczeń. Jest więc nie tylko krokiem, od którego należałoby zacząć jakikolwiek multidyscyplinarny projekt, ale również pragmatycznym ruchem w kierunku, być może, mniej ambitnym, ale nie mniej

\footnotetext{
${ }^{1}$ Visual Culture Questionnaire, „October” 1996, t. 77.
} 
istotnym. Chodzi mianowicie o próbę wyrysowania lokalnej, polskiej mapy zainteresowań, która ułatwi osobom podejmującym badania wizualne w obrębie konkretnej dyscypliny wgląd $\mathrm{w}$ to, $\mathrm{w}$ jaki sposób konceptualizuje się ten przedmiot $\mathrm{w}$ dyscyplinach pokrewnych. Pytanie drugie - Czy, jak i po co badać kulturę wizualną? - przesuwa dyskusję w kierunku odmiennych metodologii, wyrastających $z$ różnych tradycji teoretycznych, odmiennych zainteresowań badawczych i różnych sposobów wykorzystywania wyników badań, umożliwiając w ten sposób bardziej refleksyjną wymianę narzędzi badawczych i, w konsekwencji, prawdziwie multidyscyplinarną wymianę myśli.

Ocenę tego, $\mathrm{w}$ jakim stopniu udało się zrealizować tak zakreślony plan za pomocą zaproponowanej formuły, zostawiamy oczywiście czytelnikowi. To również od niego zależy, czy niniejsza publikacja przyczyni się w jakiś sposób do dalszych rozważań nad znaczeniem relacji między różnymi podejściami badawczymi dla rozwoju polskich badań nad wizualnością. Pewni jednak jesteśmy, że bez autorów poniższych wypowiedzi realizacja wspomnianego celu w ogóle nie byłaby możliwa. Pragniemy podziękować za ten ogromny wkład.

$\mathrm{Na}$ koniec kilka uwag o charakterze organizacyjnym. Poniżej, przed treścią autorskich odpowiedzi (przedstawionych w kolejności alfabetycznej), zamieszczamy wzór zaproszenia, które rozesłaliśmy rozpoczynając projekt. Chcemy $\mathrm{w}$ ten sposób dać czytelnikowi wgląd nie tylko w faktyczne brzmienie pytań, ale również $\mathrm{w}$ uzasadnienia, którymi staraliśmy się do pomysłu przekonać, a które częściowo pominęliśmy w tym krótkim wstępie. Zaproszenie kończy się listą osób, do których wysłaliśmy propozycję udziału. Niestety, do czasu tej publikacji tylko z częścią z nich udało nam się skontaktować. Nie wszyscy byli zainteresowani wzięciem udziału w projekcie, a część po prostu nie zdążyła. Mamy jednak nadzieję, że dyskusja nie skończy się wraz z poniższym tekstem. Wszyscy zaproszeni autorzy będą mieli jeszcze niejedną szansę nadesłać swoje odpowiedzi. Tym bardziej że rezultaty projektu dostępne są również na stronie internetowej http://kulturawizualna.pl, co każdemu daje możliwość nie tylko śledzenia odpowiedzi innych, lecz również zamieszczania własnych komentarzy i włączania się w dyskusję. Będziemy również starali się zapraszać osoby na wspomnianej liście nieuwzględnione, proponując udział większej liczbie przedstawicieli innych nauk oraz praktykom, by w ten sposób przełamać nazbyt widoczną dominację socjologów i badaczy $z$ ośrodka poznańskiego, a w jeszcze szerszym planie: uczonych akademickich i badaczy społecznych. Okazało się bowiem, że również inicjatorom rozesłania Kwestionariusza, mimo szczerych chęci, nie udało się uodpornić na niektóre dyscyplinarne stereotypy.

Maciej Frąckowiak, Łukasz Rogowski Instytut Socjologii UAM

Poznań, 2009/2010 kulturawizualna@gmail.com 


\section{TREŚĆ ZAPROSZENIA}

Szanowni Państwo,

W imieniu redakcji „Kultury i Społeczeństwa” oraz Zakładu Badań Kultury Wizualnej i Materialnej Instytutu Socjologii UAM mamy zaszczyt zaprosić Pana/Panią do udziału w projekcie „Kwestionariusz Kultury Wizualnej”. Projekt ma charakter interdyscyplinarny, do udziału w nim zostali zaproszeni naukowcy i artyści z całej Polski. Jego rezultaty będą opublikowane na łamach czasopisma „Kultura i Społeczeństwo” oraz zostaną wykorzystane jako wstęp do szerszej dyskusji nad stanem refleksji nad kulturą wizualną w Polsce.

Inspiracją dla twórców projektu jest artykuł Visual Culture Questionnaire, opublikowany w 1996 roku przez czasopismo „October”. Podstawę wspomnianego tekstu stanowiły sformułowane przez historyków sztuki, teoretyków filmu, krytyków literackich i artystycznych odpowiedzi na cztery obiegowe opinie o visual culture. Takie krótkie wypowiedzi, opublikowane razem i ukazujące różnorodność oraz wieloaspektowość spojrzeń na kulturę wizualną, do dzisiaj stanowią punkt odniesienia dla badaczy podejmujących w swych pracach omawiany temat.

Po trzynastu latach chcielibyśmy nawiązać do formuły kwestionariusza w polskich warunkach. Nie jest jednak naszym zamierzeniem wchodzenie $\mathrm{w}$ rolę młodszego rodzeństwa, naśladującego i kopiującego dokonania innych. Chcielibyśmy rozszerzyć pole dyskusji o te dyscypliny naukowe, które w pierwowzorze nie zostały ujęte - dlatego zadajemy pytania zarówno filozofom, historykom sztuki i filmoznawcom, jak i przedstawicielom szeroko pojmowanych nauk społecznych: socjologom, kulturoznawcom, antropologom.

Stawiamy sobie przy tym cztery cele. Pragniemy dowiedzieć się, po pierwsze, czy i w jakim stopniu interdyscyplinarny projekt badań kultury wizualnej został zrealizowany i zaaplikowany na polskim gruncie. Po drugie, chcemy poznać specyfikę rodzimej refleksji nad omawianym tematem. Po trzecie, mamy nadzieję, iż nasz kwestionariusz, ukazując różnorodność myśli i podejść teoretycznych, stanie się również - w ślad za pierwowzorem - zarówno punktem definicyjnego odniesienia, jak i elementem pobudzającym krytyczne pomysły badawcze wśród przedstawicieli różnych nauk, zafascynowanych w swojej refleksji tematem kultury wizualnej. Po czwarte w końcu, ufamy, iż wypowiedzi uczestników projektu staną się pomocnym materiałem dydaktycznym dla coraz popularniejszych kursów akademickich dotyczących kultury wizualnej.

W związku z tym chcielibyśmy poprosić Pana/Panią o krótką (maksymalnie 5 tysięcy znaków) odpowiedź na dwa ogólne pytania:

Co to jest kultura wizualna?

Czy, jak i po co badać kulturę wizualną?

Jak już zostało wspomniane, nadesłane odpowiedzi planujemy zbiorczo opublikować na łamach „Kultury i Społeczeństwa”, w numerze poświęconym 
w całości tematyce kultury wizualnej (numer 4/2009). Ufamy, że staną się one (wraz z tłumaczeniem angielskiego pierwowzoru) wstępem do otwartej dyskusji prowadzonej w szerszym gronie, początkowo na łamach dwujęzycznego internetowego blogu projektu.

Postrzegamy je również jako wstęp do cyklu otwartych seminariów prowadzonych w Instytucie Socjologii Uniwersytetu im. Adama Mickiewicza w Poznaniu, poświęconych przedmiotowi studiów wizualnych. Teksty, które powstaną $\mathrm{w}$ ramach wspomnianych seminariów, oraz wybrane wpisy na blogu złożą się na publikację książkową, stanowiącą zapis dyskusji rozpoczętej przez osoby uczestniczące $\mathrm{w}$ projekcie.

Do udziału w projekcie zostali zaproszeni ${ }^{*}$ :

Anna Bohdziewicz, Mariusz Bryl, Konrad Chmielecki, Wojciech Chyła, Hubert Czachowski, Stanisław Czekalski, Rafat Drozdowski, Paweł Dybel, Waldemar Dymarczyk, Tomasz Ferenc, Wiesław Godzic, Maria Gotębiewska, Andrzej Gwóźdź, Alicja Helman, Maryla Hopfinger, Agata Jakubowska, Krzysztof Jurecki, Jerzy Kaczmarek, Ryszard Kluszczyński, Krzysztof Tomasz Konecki, Marek Krajewski, Natalia Lach-Lachowicz, Lech Lechowicz, Jerzy Lewczyński, Zbigniew Libera, Stawomir Magala, Tomasz Majewski, Michał Markowski, Marianna Michałowska, Tadeusz Miczka, Agnieszka Ogonowska, Krzysztof Olechnicki, Michał Ostrowicki, Piotr Piotrowski, Agnieszka Rejniak-Majewska, Józef Robakowski, Łukasz Ronduda, Stawomir Sikora, Adam Sobota, Janina Struk, Piotr Sztompka, Joanna Tokarska-Bakir, Eugeniusz Wilk, Stefan Wojnecki, Piotr Wotyński, Piotr Zawojski, Anna Zeidler-Janiszewska.

\title{
ODPOWIEDZI NA KWESTIONARIUSZ
}

\author{
MARIUSZ BRYL \\ Zakład Historii i Teorii Badań nad Sztuka \\ Instytut Historii Sztuki \\ Uniwersytet im. Adama Mickiewicza w Poznaniu
}

Co to jest kultura wizualna? To całokształt procesów komunikacji wizualnej zachodzących w danym społeczeństwie. Definicja ta ma tę zaletę, że przy maksymalnej inkluzywności nie traci mocy operacyjnej, wyznaczając nie tylko obszar badawczy, ale także perspektywę teoretyczną jego konceptualizacji. Jest to perspektywa socjokulturowa, której podstawowy aksjomat — „społeczne tworzenie rzeczywistości" - odniesiony do wizualności, ulega istotnej mody-

\footnotetext{
* Kursywą wyróżniono nazwiska autorów tekstów wypowiedzi zamieszczonych poniżej (przyp. red.).
} 
fikacji, polegającej na przejściu, zgodnie ze zgrabną formułą jednego $z$ amerykańskich badaczy, od „społecznej konstrukcji tego, co wizualne”, do „wizualnej konstrukcji tego, co społeczne"; co, na innym planie, przejawia się próbą antropologicznej korekty obowiązującego dotąd, jednostronnego pansemiotyzmu. Kulturę wizualną należy zatem rozumieć jako splot wszechstronnych interakcji, jakie stają się udziałem członków danej społeczności wtedy, gdy wytwarzają artefakty wizualne, gdy nimi manipulują, gdy je interpretują („rozumieją”) itd. Interakcje owe cechuje istotowa heterogeniczność, mająca swoje źródło w nieredukowalnej dwoistości: będąc zmiennymi historycznie praktykami społecznymi, uczestniczą zarazem w antropologicznie ufundowanej ludzkiej dyspozycji widzenia (resp. obrazowania). Na nic zdały się redukcjonistyczne próby zanegowania tej dwoistości przez ortodoksyjny socjo-semiotyzm, któremu zresztą zawsze towarzyszył niebezpieczny suplement w postaci czy to psychologii percepcji, czy to neurofizjologii widzenia, odmawiających całkowitej rekuperacji wizualności przez sferę konstrukcji społecznej. Obecnie, wraz ze wspomnianą korektą antropologiczną, pojawia się nowe niebezpieczeństwo: fascynacja tak zwanym samoistnym życiem obrazów może doprowadzić do uznania ich za fenomeny, które już nie tyle „konstruują wizualnie to, co społeczne”, ale zerwawszy wszelkie więzy ze swoimi producentami i dysponentami, sprowadzają naszą rolę do statusu biernych odbiorców (konsumentów).

Na pytanie, „czy badać kulturę wizualną”, odpowiedź powinna być zdecydowanie twierdząca: oczywiście, że należy badać kulturę wizualną, albowiem stanowi ona istotny wymiar naszej tożsamości, zarówno jednostkowej, jak i społecznej. Na pytanie, ,jak badać?” — odpowiedzi może być już bardzo wiele, co wynika wprost ze wspomnianej heterogeniczności kultury wizualnej. Przy czym nie uważam za sensowne konstruowanie kultury wizualnej jako „przedmiotu, który nie należy do nikogo", po to, by ją przysposobić jako przedmiot badań dla nowej dyscypliny określającej się jako „studia nad kulturą wizualną”, zgodnie $z$ nie tak dawną propozycją znanej holenderskiej badaczki. Przeciwnie, kultura wizualna $z$ całą swoją heterogenicznością powinna - jako przedmiot badań należeć do jak największej liczby dyscyplin: od nauk przyrodniczych przez społeczne aż do humanistycznych. Do wszystkich, które uznają, że mogą wnieść wkład w badanie owych znaczących interakcji ludzkich włączających artefakty wizualne. Wkład oparty na wypracowanych w toku rozwoju danej dyscypliny, właściwych jej narzędziach badawczych, jej dyscyplinarnej kompetencji. Takie postawienie sprawy zakłada, rzecz jasna, wymianę informacji między przedstawicielami różnych dyscyplin, badających różne aspekty kultury wizualnej, ale nie zakłada koniecznego dążenia do interdyscyplinarności przedmiotu i badań (dobrze rozumiana interdyscyplinarność od dawna zresztą znajduje się już wewnątrz każdej z dyscyplin).

W obliczu tak szeroko zakrojonych badań, które nigdy nie złożą się na jednolity „produkt końcowy”, tym większą wagę ma odpowiedź na ostatnie pytanie: „po co badać kulturę wizualną"? Na poziomie podstawowym odpowiedź ta za- 
leży od wspomnianej „dyscyplinarnej kompetencji”, która w przypadku mojej dyscypliny, historii sztuki, polega na doskonalonej przez dwieście lat umiejętności analizy znaczącej struktury artefaktów wizualnych (wszelkich, nie tylko tych kwalifikowanych artystycznie). Na poziomie głębszym natomiast zależy od przyjętej przez badacza hierarchii wartości. W tym kontekście pozwolę sobie przytoczyć cel, jaki postawiłem przed „oświeconą krytyką obrazów” jako odpowiedzią mojej dyscypliny „na wyzwanie współczesnej polityki i ekonomii obrazowej, w ramach której media obrazowe stają się obszarem praktykowania szeroko pojętej władzy. Historia sztuki powinna przy tym jasno określić cel w tym przypadku par excellence polityczny — jakiemu miałaby służyć jej analityczno-krytyczna praca w tym obszarze. Musiałaby być ona nakierowana na obronę danej wspólnoty przed przemocą ze strony wszelkiego rodzaju producentów obrazów rozpowszechnianych za pomocą wszelkich mediów, z reguły - choć nie zawsze - w masowej skali. Przemoc ta, która przybierać może najróżniejsze formy, zarówno intencjonalne (świadoma manipulacja, mistyfikacja, zafałszowanie przekazu itd.), jak i obiektywne (związane z naturą samego medium), a którą określa się niekiedy mianem przemocy "symbolicznej» lub «medialnej», stanowi zagrożenie dla integralności danej społeczności, niszcząc autentyczne formy komunikacji między jej członkami. Tego rodzaju «krytyka obrazów» nie miałaby charakteru globalnego, ale właśnie lokalny, wypełniałaby przede wszystkim powinność względem konkretnej wspólnoty, poddanej władzy konkretnych obrazów tworzonych i rozpowszechnianych przez określonych producentów i dysponentów $\mathrm{w}$ ściśle określonych kontekstach $\mathrm{i}-\mathrm{z}$ reguły w określonym celu, interesie lub — jedynie — skutkując określonym efektem u ich odbiorców" 1 .

\section{KONRAD CHMIELECKI}

Zaktad Kultury i Sztuk Wizualnych

Instytut Kulturoznawstwa

Akademia Humanistyczno-Ekonomiczna w Łodzi

Termin „kultura wizualna” (visual culture) jest rozumiany, w dość mylący sposób, zarówno jako dziedzina wiedzy, jak i przedmiot badań, a jego definicja nastręcza teoretykom trudności. Jednym z często praktykowanych sposobów wyjaśnienia, czym jest kultura wizualna, jest metoda przyjęta po raz pierwszy przez Williama J. Thomasa Mitchella, który stwierdził, że nie można przyjąć ogólnie dostępnego znaczenia słów „wizualny” i „kultura” do stworzenia satys-

1 M. Bryl, Suwerenność dyscypliny. Polemiczna historia historii sztuki od 1970 roku, Wydawnictwo UAM, Poznań 2008, s. 688-689. 
fakcjonującej definicji kultury wizualnej ${ }^{1}$. Wychodząc $z$ tego właśnie założenia Malcolm Barnard postanawia poświęcić cały rozdział swej książki próbie zdefiniowania pojęć „wizualny” (the visual) i „kulturowy” (the cultural), aby stworzyć kontekst dla dalszych rozważań na temat visual culture ${ }^{2}$.

Wśród określeń pierwszego $z$ wymienionych terminów, jakie podaje badacz, pojawiają się na przykład takie sformułowania jak: „wszystko, co możemy zobaczyć”, „wszystko produkowane albo tworzone przez ludzi, co można zobaczyć”, „funkcjonalny i komunikacyjny cel: design”, „cel estetyczny: sztuka”. Omówienie wszystkich wymienionych określeń zajęłoby dużo miejsca, ale ciekawym może się wydać to, że wśród różnych materiałów, z których kreowane i produkowane są przez człowieka obrazy, Barnard wymienia również mocz (urynę) przywołując słynną fotografię Andresa Serrano Piss Christ (1987) i rzeźby Helen Chadwick Piss Flowers (1991-1992) ${ }^{3}$.

Opisane zabiegi w gruncie rzeczy prowadzą do coraz bardziej „globalnego” znaczenia tego terminu. Zamiast precyzowania, teoretycy mnożą konteksty, w których można mówić o różnych aspektach wizualności w kulturze, ale również wizualności kultury współczesnej. Dość wspomnieć, że Barnard po kilku latach porzucił szeroką koncepcję kultury wizualnej na rzecz opisu kilku perspektyw teoretycznych (feminizm, marksizm, semiologia, ikonografia i ikonologia), które miałyby służyć do zrozumienia terminu kultury wizualnej ${ }^{4}$.

Nicholas Mirzoeff utożsamia „kulturę wizualną” z kierunkami badań, które dotyczą:

— zdarzeń wizualnych (visual events), w których konsument poszukuje informacji, znaczenia albo przyjemności, uzyskiwanych dzięki narzędziom i wizualnym technologiom, czyli konkretnym obiektom, przedmiotom patrzenia, jak i środkom służącym do ich prezentacji: od fresków i obrazów olejnych, poprzez fotografię, film, telewizję, aż po (multi)media cyfrowe oraz internet ${ }^{5}$;

- historii obrazów (the history of images) opartej na semiotycznym pojęciu przedstawienia (representation) ${ }^{6}$;

- społecznej teorii wizualności (social theory of visuality) albo socjologii kultury wizualnej (sociology of visual culture), która stara się wypracować własną metodologię, de facto izolującą wizualność od zmysłów

\footnotetext{
1 W. J. T. Mitchell, What Is Visual Culture?, w: I. Lavin (red.), Meaning in the Visual Arts: Views from the Outside, Princeton University Press, Princeton 1995, s. 208.

2 M. Barnard, Art, Design and Visual Culture: An Introduction, St. Martin's Press, New York 1998, s. $10-31$.

3 Tamże, s. 13.

4 M. Barnard, Approaches to Understanding Visual Culture, Palgrave, New York 2001.

5 N. Mirzoeff, An Introduction to Visual Culture, Routledge, London-New York 2003, s. 1-33.

${ }^{6}$ N. Bryson, M. A. Holly, Keith P. F. Moxey (red.), Visual Theory: Painting and Interpretations, Harper Collins Publishers, Cambridge 1991; zob. też: N. Bryson, M. A. Holly, Keith P. F. Moxey (red.), Visual Culture: Images and Interpretations, University Press of New England, Hanover 1994.
} 
i przesuwającą punkt ciężkości na problematykę społeczną i socjologiczną, poruszając zagadnienia tożsamości (gender) czy interakcji społecznych ${ }^{7}$.

Określenie kultury wizualnej można odnosić do „zdarzenia wizualnego”. Mirzoeff próbuje umieścić to pojęcie w kontekście kultury postmodernizmu, którą rozumie jako „kryzys” modernizmu albo nowoczesności, ujawniający upadek charakterystycznej strategii wizualizacji. W tym sensie postmodernizm jest de facto „kryzysem” modernizmu, ale dokonującym się w wymiarze wizualnym. Przesunięcie ciężaru gatunkowego z tekstualności na wizualność współczesnych przemian kulturowych pozwala zrozumieć specyfikę omawianego zjawiska ${ }^{8}$. Jednak wypowiadając się na temat „kultury wizualnej” Mirzoeff stwierdza, że:

„[...] w coraz większym stopniu staje się [ona — przyp. K. C.] miejscem spotkania krytyków, historyków i praktyków wszelkich mediów wizualnych, zniecierpliwionych wymęczonymi banałami ich «macierzystych» dyscyplin [...]. Ta konwergencja jest możliwa i podtrzymywana przede wszystkim dzięki technologii digitalnej (Cartwright). Pojawienie się multimediów skutkowało na północnoamerykańskich uniwersytetach swoistym stanem wyjątkowym odnośnie analizy krytycznej, pedagogiki i praktyki instytucjonalnej" 9 .

W dalszej części tekstu Mirzoeff precyzuje ten termin następująco:

„Kultura wizualna nie jest zatem tradycyjną dyscypliną, ponieważ już od dłuższego czasu może w ogóle nie istnieć coś takiego jak współczesny ciąg dyscyplin. Można ją raczej uznać za jedno z krytycznych narzędzi służących do wypracowania formuły postdyscyplinarnej praktyki i zarazem do kontroli i gwarancji, iż praktyka ta nie jest po prostu jakąś formą treningu przedzawodowego. Oznacza to na przykład, że należy podjąć próbę wynalezienia właściwych sposobów refleksji na tym, jak oddziałuje kultura wizualna i dlaczego właśnie tak, a nie inaczej, a nie po prostu ograniczać się do nauczania software, czy to w sensie praktycznych umiejętności, czy jako to, co Lev Manovich określa mianem software studies" 10 .

Celem kultury wizualnej jest więc wypracowanie metod i narzędzi służących do analizy współcześnie zachodzących zjawisk w sferze wizualnej. Jednak w jakim stopniu jest to możliwe, to już osobna kwestia, która wymaga wyjaśnienia w innym tekście.

Czy, jak i po co badać kulturę wizualną? Zachodzące współcześnie transformacje w wizualnej sferze kultury trudno pominaćc. Wydaje się więc, że istnieje potrzeba badań nad tym wymiarem ikonosfery i jest to bardzo ważny aspekt badań nad kulturą. Dlatego też podejmuje się wiele prób wypracowania własnej

${ }^{7}$ Ch. Jenks (red.), Visual Culture, Routledge, London-New York 1995.

8 N. Mirzoeff, An Introduction..., cyt. wyd., s. 3.

9 N. Mirzoeff, Podmiot kultury wizualnej, tłum. M. Bryl, w: P. Piotrowski, W. Suchocki (red.), „Artium Quaestiones” XVII, Wydawnictwo Naukowe UAM, Poznań 2006, s. 252.

10 Tamże, s. 253. 
metodologii i narzędzi analizy. Nicholas Mirzoeff proponuje metodę interdyscyplinarną, która wykorzystuje zdobycze wielu nauk humanistycznych zajmujących się badaniem różnych przejawów wizualności ${ }^{11}$. Spektrum pojawiających się tutaj teorii jest bowiem bardzo szerokie. John A. Walker i Sarah Chaplin próbują prześledzić wszystkie perspektywy teoretyczne studiów nad kulturą wizualną, wymieniając samodzielne dyscypliny i szkoły metodologiczne, które mogą być w nich wykorzystane. Według tych badaczy są to między innymi: antropologia, archeologia, ekonomia polityczna, estetyka, feminizm, fenomenologia, filmoznawstwo, filozofia poststrukturalizmu, historia społeczna, historia i teoria architektury, historia i teoria sztuki, językoznawstwo, medioznawstwo, psychoanaliza, psychologia poznania, semiotyka, socjologia, studia afroamerykańskie, studia kulturowe i teoria fotografii ${ }^{12}$.

W gruncie rzeczy ten kompleks dziedzin, które koegzystują, staje się bardziej strategią aniżeli dyscypliną akademicką ${ }^{13}$. Jako przykład rozwoju wspomnianej tendencji na obszarze studiów nad kulturą wizualną można podać refleksję nad zjawiskiem „kulturowej reprezentacji”, która obecnie analizowana jest w perspektywie interdyscyplinarnej: od malarstwa, poprzez fotografię, film, telewizję i wideo, aż po interaktywne multimedia cyfrowe ${ }^{14}$. Być może najtrafniejszą diagnozą rozwijających się obecnie tendencji, które mają decydujący wpływ na charakter studiów nad kulturą wizualną, jest stwierdzenie Irit Rogoff:

„Kultura wizualna otwiera cały świat intertekstualności, w którym obrazy, dźwięki i przestrzenne współrzędne odczytywane są jedne poprzez drugie, z zapożyczeniem nagromadzonych warstw znaczenia i subiektywnych reakcji na każde nasze spotkanie $\mathrm{z}$ filmem, telewizją, przedmiotem sztuki, budynkiem czy środowiskiem miejskim" ${ }^{15}$.

Zaprezentowany kontekst teoretyczny jest efektem ponowoczesnej pluralizacji kultury starającej się rozstrzygać o tych samych problemach w kilku kwestiach. Przedstawiony projekt szczególnie mocno ciąży w kierunku interdyscyplinarności, która wyjątkowo często powraca we wszelkich diagnozach metodologicznych dotyczących rozwoju kultury wizualnej. Jednak czy to wystarczy, aby stwierdzić, że potrzeba badań nad kulturą wizualną jest bezsporna?

Obecnie trudno jednak rozstrzygnąć, jakie efekty przyniesie zastosowanie metody interdyscyplinarnej $\mathrm{w}$ badaniach nad kulturą wizualną. Jest to spowodowane dużymi obciążeniami wynikającymi z zastosowania jej w wielu dyscyplinach. Trudno również przewidzieć korzyści płynące $z$ takich badań. $Z$ jednej

${ }^{11}$ N. Mirzoeff, An Introduction..., cyt. wyd., s. 3-5.

12 J. A. Walker, S. Chaplin, Visual Culture: An Introduction, Manchester University Press, Manchester-New York 1998, s. 1-6.

13 I. Rogoff, Studying Visual Culture, w: N. Mirzoeff (red.), The Visual Culture Reader, Routledge, London-New York 2002, s. 24-36.

14 L. Cartwright, M. Sturken, Practices of Looking: An Introduction to Visual Culture, Oxford University Press, Oxford-New York 2001, s. 109-150.

15 I. Rogoff, Studying Visual Culture, cyt. wyd., s. 31. 
strony ich potrzeba wydaje się bezdyskusyjna. Z drugiej zaś strony rozwój tego typu badań powoduje zanik specyfiki i autonomii poszczególnych dyscyplin. O dalszym rozwoju badań nad kulturą wizualną może również przesądzić transformacja refleksji nad nowymi mediami, która znalazła już przychylny kontekst teoretyczny w ramach badań nad kulturą wizualną. Być może jest to pierwszy krok na drodze: od interdyscyplinarnej teorii obrazu w kierunku badań nad cyberkulturą. Jednak na definitywne rozwiązanie tej kwestii przyjdzie nam jeszcze poczekać.

WOJCIECH CHYŁA

Zaktad Badań nad Kultura Filmowa i Audiowizualna

Instytut Kulturoznawstwa

Uniwersytet im. Adama Mickiewicza w Poznaniu

Postrzegam i interpretuję pojęcie kultury wizualnej nie jako kontynuację historii sztuki po historii sztuki, zgodnie $z$ intencjami twórców tego pojęcia, ale $\mathrm{w}$ kontekście zyskiwania dziś w kulturze przewagi przez techniki uobecniania bycia nad tradycyjnym językowym przywodzeniem go sobie na myśl przez człowieka. Albowiem konstatując dziś rosnącą siłę kultury wizualnej, asystujemy po prostu wzrostowi znaczenia technicznie innowacyjnego i inwencyjnego uobecniania tego, co samo $z$ siebie się nie uobecnia $\mathrm{w}$ zastanych naturalno-ewolucyjnych warunkach, gdy jednocześnie kurczy się pole językowe samodzielnego przywodzenia sobie przez ludzi na myśl tego, co aktualnie nieobecne. Postrzegam więc rozwój kultury wizualnej na tle rosnącego konkurowania technologii fantazjowania ludziom nowych możliwości bycia z językowym odkrywaniem, ustalaniem i inwentaryzowaniem przez nich językowo rozpoznawalnych i definiowalnych form bycia. Jako walka między widzeniem technicznie uobecnianego nam bycia a myśleniem językowo jedynie wypowiadanego przez nas wszelkiego istnienia jest to walka pomiędzy doksą technicznie nam warunkowaną - i nieskończenie nam automatycznie pomnażaną a episteme językowo-dyskursywnie, historycznie rozwijanych przez nas epok kultury. Walka i jej rezultat, który sprowadza się do ogólnego urzeczywistniania się w naszym obecnym świecie Wittgensteinowskiego okrzyku: „Nie myśl, tylko patrz", patrz na to, co ci akurat jest technicznie uobecniane. Trać zatem swoją samodzielność myślenia i odpowiedzialność mówienia na rzecz narzucanej pseudorelacji o charakterze wzrokowego kontaktu $z$ obiektami nieświadomościowego fantazjowania, relacji o charakterze katalizatora afektywnej dynamiki, mającej na celu zwiększanie wartości przyjemności.

Wiemy więc, po co pojawia się w kulturze i wciąż, i wciąż rośnie w siłę kultura wizualna. Po pierwsze, pojawia się, bo wartość przyjemności tkwi w jej zdolności do wzbogacania relacji o afektywną dynamikę. Po drugie, wciąż 
i wciąż rośnie w siłę, bo wartość przyjemności tkwi w jej natychmiastowej konwersji na ekonomiczną wartość dodaną, co umożliwiają rozwijające się wciąż techniczne media kultury wizualnej. Media zaprowadzające technokomunikację i technomerkantylizm.

Kultura wizualna jest więc „urządzeniem mocy” przyjemności i urządzeniem spekulowania tą mocą, a zarazem jest też urządzeniem przemieniania tego spekulowania $\mathrm{w}$ spekulację finansową. Jest ona coraz bardziej urządzeniem do zaprowadzania ekonomii finansów, bo umożliwia jej oddzielenie od delokalizowanej w regiony przedprzemysłowe ekonomii produkcji. Kultura wizualna to dziś meganarzędzie ekonomii finansów dezindustralizujące społeczeństwa dotąd industrialne, delokalizujące przemysł ekonomii produkcji na łono społeczeństw przedindustrialnych. Dlaczego? Dlatego, że kreując technicznie interaktywny „prosumariat”, kultura ta daje pracę jej konsumentom, aby koprodukowali to, co nabywają. Aby zdolni byli myśleć wizualnie, znaczy to - przedmiotowymi przedstawieniami ich własnego pragnienia, rzutowanymi im na ekrany w toku technicznego stawania się na tych ekranach nie ich wspomnienia, ale technicznego wspominania-wyobrażania-uobecniania zestawianego z „bazy danych" - z technicznej pamięci mediów kultury wizualnej. Sączącego się po to, by każdy z nas był zdolny wyjść poza własną pamięć, a zatem i własną indywiduację, kiedy myśli nie z ograniczonych pozycji swego ciała, ale z pozycji wszechwidzenia dawanych mu przez kulturę wizualną. Dawanych jako nieustające technokoneksjonistyczne zdarzenia tej kultury, będące wynikiem technicznie otrzymywanej wielości punktów widzenia, czyli perspektyw. Bezśrodkowa wielość perspektyw jest tu bowiem zdarzeniem.

Kultura wizualna to zatem „elektroniczny sen, w którym mają udział wszystkie pamięci" (Douglas Coupland), sen kontrolujący całe społeczeństwa stające się przez ów sen „społeczeństwami kontroli” i pluralizującej się w nieskończoność doksokracji, w warunkach rzeczywistego upadku demokracji przedstawicielskiej, technicznego ukartowania kryzysu tożsamości wchodzącego na miejsce polityki oraz rzeczywistego proletaryzowania się konsumpcji i konsumentów wraz z potanianiem zarówno delokalizowanej, jak i prosumenckiej produkcji.

Podsumowując:

Postrzegam i interpretuję pojęcie kultury wizualnej nie jako kontynuację historii sztuki po historii sztuki, ale przede wszystkim jako kontynuację ekonomii w epoce jej dążenia do swej własnej transgresji w kierunku absolutu, dążenia spełniającego się $\mathrm{w}$ „ekonomii niematerialności”, umożliwianej oraz już realizowanej przez media kultury wizualnej. Kultura wizualna w tej perspektywie to kontynuacja ekonomii w epoce jej roszczeń absolutnych, a więc zgłaszanych i realizowanych przez samą ekonomię zaprowadzaną przez kulturę wizualną. Jak, w jaki sposób ma to być kontynuacja ekonomii? Jako jej technokomunikacyjna, technomerkantylna maksymalizacja: spekulacja pragnieniem i spekulacja wartością rynkową wszystkiego, co techniczno-medialnie zmysłom 
jest uobecniane, a także jako technokoneksjonistycznie programowane i interakcyjnie reprogramowane zdarzenia, będące zarazem konsumpcją i produkcją, odbiorem i kreacją.

W sprawie drugiego pytania, jak badać kulturę wizualną, odpowiem, że odpowiednią dla mnie metodą badania wskazanych wyżej cech kultury wizualnej jest filozoficzna krytyka kultury. Aby uzasadnić bliżej, dlaczego tak uważam, odsyłam do „słowa wstępnego" mojego autorstwa w książce z materiałami $z$ konferencji „Badania nad mediami w perspektywie kulturoznawczej. Kultura medialnie zapośredniczona" ${ }^{1}$.

HUBERT CZACHOWSKI

Muzeum Etnograficzne w Toruniu

Często jest tak z próbami definicji, że im dłużej się nad nimi zastanawiamy, tym trudniej jest dojść do jednej, spójnej konkluzji. W moim przypadku jest tak z pojęciem kultury wizualnej (lub jakimś jej inaczej nazwanym ekwiwalentem typu „kultura obrazu”). Dlaczego się tak dzieje? Bo przeglądając literaturę na ten temat widzę, jak bardzo różnie podchodzi się do takich zjawisk. Główne miejsce $\mathrm{w}$ pracach o wizualności zajmuje fotografia. I to, od razu dodajmy, fotografia bardzo różna - od awangardowych wystąpień artystycznych, poprzez reklamę i fotografię prasową, aż do fotografii amatorskiej, turystycznej, rodzinnej, prywatnej. Pomimo że używane jest to samo medium, są to światy często zupełnie odrębne i wymagające zupełnie innego namysłu badawczego. Do tego dochodzi teraz fotografia z telefonów komórkowych i takież filmy. No właśnie, film lokuje się tuż za fotografią wśród „wizualnych” dziedzin. I tu pojawia się pierwsza wątpliwość. Przede wszystkim widzę bowiem „napięcie” między podejściem wywodzącym się z „historii sztuki” a tym z nauk społecznych. Po prostu artystyczną wypowiedź z użyciem fotografii czy filmu widzę bliżej świata sztuki (oczywiście, są świadome próby łączenia tych przestrzeni).

Jeżeli jednak perspektywa artystów fotografii, filmu, wideo mieści się w kulturze wizualnej, dlaczego mniej atrakcyjne w tym kontekście wydają się przedsięwzięcia performerów czy scenografów teatralnych? Bo nie jest możliwa ich „reprodukcja”? A co zrobić z architektami, których dzieła są „wizualne” per se? A co z modą?

Czyżby więc termin „kultura wizualna” dotyczył tylko nowych mediów fotografii, filmu, internetu? Nie wydaje mi się to dobrym pomysłem, a jeżeli do tego mielibyśmy się ograniczyć, to może lepszy byłby termin inny, nieanektujący pól jednak odrębnych. Bo na przykład co wtedy z reklamą uliczną? Podejrzewam, że większość bez wahania zaliczy ją do kultury wizualnej.

\footnotetext{
${ }^{1}$ Kultura medialnie zapośredniczona. Badania nad mediami w perspektywie kulturoznawczej, W. Chyła, M. Kamińska, M. Kosińska, P. Kędziora (red.), Wydawnictwo Naukowe Bogucki, Poznań, w druku.
} 
O wizualności współczesnej kultury ma dowodzić także rozwój internetu. I oczywiście, jest prawdą, że medium to w sposób doskonały (w sensie jego produkcji i rozpowszechniania) operuje obrazem, wizualnością. Ale nie zapominajmy, że także słowo zyskało w świecie wirtualnym nieznaną do tej pory siłę rozwoju. Mówię to dlatego, że nie sposób ograniczyć (czy nawet wyodrębnić) tylko części wizualnej w internecie. To zbyt duże uproszczenie. Fotoblogi są obecnością dzisiejszego świata, ale to często „zwykłe” blogi mocniej oddziałują na współczesną kulturę, politykę i historię.

Drugi powód wywołujący u mnie terminologiczne niejasności wynika być może z faktu, że prowadziłem zarówno badania dotyczące współczesności, jak i czysto historyczne. I wtedy okazuje się, że ta wizualność kultury współczesnej jako jej cecha podstawowa (przynajmniej tak często jest to formułowane) już wcześniej występowała w wielu epokach i tam także odgrywała bardzo ważną rolę (oczywiście, takie badania historyczne odwołujące się do pojęcia „kultura wizualna" są prowadzone). Weźmy też pod uwagę doświadczenie płynące z szerszych badań etnologicznych i przykłady z innych kultur. Owszem, są to kultury oralne, ale bynajmniej nie zamknięte na obraz i — co za tym idzie - realizujące się poprzez wizualność także w dość zasadniczym wymiarze. Przywołajmy rozmaite obrzędy, widowiska, sposoby dekoracji ciała, uczesania, gesty.

Jeżeli tak, to powstaje pytanie, czy badania tego typu także należą do obszaru badania kultury wizualnej? Osobiście nie widzę żadnego merytorycznego powodu (oprócz etnocentryzmu), żeby takie badania osadzać w innej perspektywie. Oczywiście, będą różnice jakościowe między współczesną ikonosferą wioski Indian Keczua a Manhattanem, ale będą one dotyczyły rodzaju wytwarzanego obrazu, ich funkcji, ale nie ważności w całej układance kultury.

W takim razie jak badać coś tak nieokreślonego jak kultura wizualna? Myślę, że nadal to pojęcie (na swój sposób potrzebne, bo zwracające uwagę na odrębny aspekt rzeczywistości) inaczej będzie pojmowane w studiach artystycznych, socjologicznych, etnologicznych, semiotycznych, przynajmniej dopóki takie dyscypliny będą istniały.

\section{STANISEAW CZEKALSKI}

Zakład Historii $i$ Teorii Badań nad Sztuka

Instytut Historii Sztuki

Uniwersytet im. Adama Mickiewicza w Poznaniu

„Kultura wizualna” jest bardzo nieprecyzyjnym określeniem szerokiego nurtu zainteresowań problematyką wizualności i jej związków z różnymi praktykami kulturowymi społeczeństw. Jakkolwiek można ten kierunek refleksji wywodzić z zainicjowanych na gruncie historii sztuki przez Aby Warburga studiów nad przekraczającymi kontekst artystyczny funkcjami obrazów w danej kulturze, rozumiem dzisiaj dyskutowane pojęcie kultury wizualnej przede 
wszystkim jako tyleż nośne, co ogólnikowe hasło wywoławcze, dla którego próbuje się znaleźć realny desygnat w jakimś przedmiocie badań, ten jednak pozostaje nieustalony i raczej rozmywa się niż konkretyzuje w efekcie jałowych sporów definicyjnych. Istotną przesłanką projektu rozwinięcia studiów nad kulturą wizualną było przeświadczenie, że muszą one wykroczyć poza granice pól badawczych poszczególnych dyscyplin nauki, które nie są w stanie rozpoznać całej złożoności i wieloaspektowości związków pomiędzy tym, co wizualne, a tym, co kulturowe. Imperatyw poszerzenia obszaru badań okazał się jednak kłopotliwy: ponieważ dla współczesnego rozumienia dziedzin zarówno kultury, jak i wizualności charakter paradygmatyczny ma model bezkresnej sieci wielokierunkowych relacji, każda rama wyodrębniająca domenę kultury wizualnej od zjawisk wobec niej zewnętrznych musi się okazać zbyt ciasna. Uchwytna jest jednak centralna oś problemowa, która organizuje obraz tego skądinąd bezkresnego obszaru, wyznacza perspektywę jego analizy. Stanowi ją pojęcie wizualności jako pola widzenia kształtowanego przez dyskurs, ideologie i stosunki władzy. W efekcie studia nad kulturą wizualną nader często przybierają postać krytyki ideologicznej, która reprezentuje mniej lub bardziej radykalnie lewicową orientację polityczną.

W obliczu trudności z pozytywną definicją kultury wizualnej jako dziedziny badań potrzebę jej rozwijania uzasadnia się w trybie negatywnym, przez krytykę ograniczeń tradycyjnych dziedzin nauki zajmujących się jedynie pewnymi wycinkami obszaru wizualności, i to w zbyt wąskiej lub wręcz niewłaściwie ustawionej perspektywie badawczej. Głównym adresatem tej krytyki pozostaje historia sztuki, definiowana przez zamknięcie w kręgu dzieł wizualnych kwalifikowanych jako artystyczne i w kręgu dociekań na temat historycznych czynników ich powstania. Jeśli więc kultura wizualna stanowić ma pozytywną alternatywę dla tak zawężonego horyzontu historii sztuki, to rysuje się spór o to, czy dobrym wyjściem jest otwarcie tej dyscypliny na ikonosferę pozaartystyczną i na inne rozumienie jej historycznego wymiaru niż to związane $z$ perspektywą genezy, czy też należy historię sztuki odesłać do lamusa i zastąpić nową dyscypliną studiów nad wizualnością.

Zdecydowanie opowiadam się za poszerzaniem zakresu refleksji nad wizualnością $\mathrm{w}$ jej różnych kulturowych aspektach na gruncie historii sztuki (podobnie jak na gruncie innych dyscyplin), natomiast przeciwko wypychaniu historii sztuki z tego obszaru refleksji w imię mglistego projektu nauki o kulturze wizualnej jako nowej mega- czy multidyscypliny, która ostatecznie miałaby zająć jej miejsce nie tylko w wymiarze intelektualnym, lecz także instytucjonalnym. W ciągu ostatnich dziesięcioleci historia sztuki zdążyła już bardzo dobrze się wykazać zdolnością produktywnego otwarcia na problemy badawcze z zakresu kultury wizualnej daleko wykraczające poza obszar jej tradycyjnych zainteresowań, w obrębie którego krytycy rzekomych ograniczeń tej dyscypliny chcieliby ją zamknąć. Potrafiła ona na tyle owocnie wykorzystać inspiracje płynące $z$ różnych innych dziedzin wiedzy, sięgać po nowe, gdzie 
indziej stosowane narzędzia analityczne, że może wręcz służyć przykładem takiego właśnie otwartego i chłonnego nastawienia na wielowymiarowe badanie zjawisk kultury wizualnej. Dalszy sensowny rozwój studiów prowadzonych pod tym hasłem wyobrażam sobie tylko na podobnej zasadzie - poprzez intensywną wymianę wiedzy, teorii, metod i doświadczeń badawczych między różnymi istniejącymi dyscyplinami naukowymi, których osiągnięcia mogą służyć lepszemu, wielostronnemu rozpoznaniu związków między wizualnością i kulturą. Hasło „kultura wizualna” powinno zatem przyświecać budowaniu forum interdyscyplinarnego dialogu, nie zaś tworzeniu jakichś nowych bytów instytucjonalnych i akademickich - dyscyplin naukowych, kierunków studiów itd., które miałaby ona albo wchłonąć, albo wyprzeć te dotychczas funkcjonujące. $\mathrm{W}$ takim dialogu równie istotne byłoby możliwie gruntowne czerpanie przez poszczególne dyscypliny nauki z dorobku innych, co wzajemne krytyczne sprawdzanie efektów wypraw badawczych na teren kultury wizualnej, podejmowanych $z$ odmiennych stron. Koniecznym warunkiem dobrej współpracy między różnymi dyscyplinami jest przyjęcie zasady respektowania odrębnych, szczególnych kompetencji, jakie każda z nich zachowuje w rdzennym dla niej zakresie badań. Zwrot ku poszerzaniu i przenikaniu się tych zakresów nie może wszak oznaczać rezygnacji ze standardów rzetelności i warsztatowej solidności, które obowiązują na gruncie poszczególnych nauk. Należałoby na przykład sprawdzić, w jakim stopniu faktycznie prawomocny może być zarzut „wizualnego esencjalizmu" (Mieke Bal) i w jakim stopniu doświadczenie wzrokowe jest faktycznie poddane zależnościom od wiedzy, dyskursu, ideologii itd. odwołując się do badań z zakresu psychologii widzenia. Oceniając w świetle powyższych zasad poziom, jaki reprezentują analizy wizualności obrazów podejmowane przez wielu badaczy, tyleż chętnych do wejścia w ten obszar z zewnątrz historii sztuki, co ignorujących warsztat analityczny aktualnie stosowany w jej obrębie - wrażenia mam nie najlepsze. Wiążą się one także z dojmującym poczuciem, że wpisane niejako z góry w ideę kultury wizualnej założenie podatności tego, co oglądowe, na to, co dyskursywne, ideologiczne i polityczne, pozostaje mniej uzasadnione naukowo niż wynika to $z$ politycznego myślenia.

RAFAE DROZDOWSKI

Zakład Socjologii Życia Codziennego

Instytut Socjologii

Uniwersytet im. Adama Mickiewicza w Poznaniu

Co to jest kultura wizualna? Szczerze mówiąc, najchętniej poprzestałbym na stwierdzeniu „co to jest kultura wizualna, każdy widzi...”. Zdrowy rozsądek nakazuje bowiem nie dać się sprowokować do próby sformułowania kolejnej 
definicji kultury wizualnej, która najpewniej — jak setki jej poprzedniczek — nie będzie zadowalająca. Co więcej, każda nowa próba odpowiedzi na pytanie, czym jest kultura wizualna (a przy okazji pewnie i na pytanie, czym ona nie jest, bądź czym być nie powinna), będzie nas prawdopodobnie - w ostatecznym rozrachunku - raczej zamykać na obrazy (przynajmniej na niektóre $z$ nich).

Rozumiem jednak, że aż tak łatwo się nie wykręcę. Przyparty do muru, powiedziałbym zatem, że kultura wizualna to dla mnie suma wyborów/działań i ich rezultatów (niekoniecznie wizualnych), które wyniknęły/wynikają z przekonania, że obrazy są - w taki czy inny sposób - ważne (jako świadectwa, jako narzędzia mediacji, jako substytuty, jako kotwice pamięci, jako źródła takich czy innych przyjemności, jako wątpliwe reprezentacje lub wręcz jako zafałszowania rzeczywistości, którym trzeba się aktywnie przeciwstawiać, jako przypomnienia o kłopotliwych i w gruncie rzeczy niezinternalizowanych zobowiązaniach, jako intrygujące, ale też irytujące zagadki, jako potwierdzenia bądź zaprzeczenia „reżimów codzienności”, jako instrukcje, jako zadania - do powtórzenia albo do wykonania, jako preteksty do rozmów, jako przedmioty itd.).

Fundamentem i warunkiem kultury wizualnej nie jest więc ani obrazocentryzm (ilościowa dominacja obrazów), ani wzrokocentryzm (jakieś specjalne zaufanie do zmysłu wzroku i do obrazów). Jest nim dopiero (słuszne bądź niesłuszne - to całkiem inna sprawa) przeświadczenie, że nie da się żyć bez obrazów (nawet jeśli się nie jest ich fanem i nawet jeśli się nimi pogardza) oraz że obrazy mają swój istotny udział zarówno w procesie reprodukcji, jak i w procesie wytwarzania wszystkich najważniejszych reguł porządku społecznego (częstokroć występując zresztą w tej roli w skórze podwójnego agenta, który „gra równocześnie na dwie bramki").

Przyjąwszy takie rozumienie kultury wizualnej, należałoby jeszcze dla porządku dodać, że tkwimy w niej po uszy, odkąd mamy oczy.

„Czy, jak i po co badać kulturę wizualną?” - to tak naprawdę aż trzy pytania... Ograniczę się $\mathrm{w}$ tym miejscu do próby odpowiedzi na pytanie, jak badać kulturę wizualną.

Po pierwsze, badanie kultury wizualnej nie musi być (a może nawet nie powinno być - tak w przeszłości, jak i obecnie) równoznaczne $z$ badaniem obrazów (ich wyglądu, wszytych w nie znaczeń, „zadanych” im funkcji wzorcotwórczych i regulacyjnych itd.). Znacznie bardziej obiecująca wydaje mi się taka strategia badawcza, która jest oparta na założeniu, że bardziej niż samymi obrazami warto interesować się tym wszystkim, co je poprzedza, i tym wszystkim, co wiąże się ze sposobami ich społecznego uwidzialniania. Co to oznacza (co to może oznaczać) w praktyce? Najkrócej mówiąc - program, w myśl którego przedmiotem socjologicznego zainteresowania i socjologicznej uwagi przestaje być sama wizualność, staje się nim natomiast szerokie spektrum rozmaitych mikropraktyk związanych (1) z fazą powstawania obrazu i (2) ze sposobami zarządzania obrazami, ze sposobami włączania 
ich (względnie wyłączania) z konstruowanych przez jednostki ich własnych, prywatnych scenografii, w których rozgrywa się ich życie codzienne.

Po drugie, wydaje mi się, że warto dziś badać kulturę wizualną $\mathrm{w}$ taki sposób, aby - przede wszystkim — próbować wyśledzać i ustalać związki, jakie zachodzą między zmysłem wzroku a wszystkimi pozostałymi zmysłami. Poszedłbym tu nawet o krok dalej: warto badać kulturę wizualną nie tyle już z perspektywy oka i zmysłu wzroku, ile traktując jako najważniejszą kwestię badawczą pytanie o jej implikacje dla reszty zmysłów, pytanie o to, czy i jak zmienia ona ich kulturowy status.

Postulat badania kultury wizualnej z perspektywy „zmysłów niewzrokowych" jest równoznaczny z przekonaniem, że (przynajmniej w przypadku kultury wizualnej) lepszą, bardziej efektywną i po prostu bardziej ciekawą strategią badawczą powinna okazać się „strategia relacyjna”, która dąży do ujawnienia charakteru kultury wizualnej nie poprzez uporczywe badanie jej struktury wewnętrznej i jej przejawów, ale poprzez wskazywanie na jej powiązania $z$ tym wszystkim, co (trafnie lub nietrafnie) sytuujmy dzisiaj poza jej granicami.

WALDEMAR DYMARCZYK

Katedra Socjologii Organizacji i Zarzadzania

Instytut Socjologii

Uniwersytet Łódzki

Odpowiadając na pytanie: „co to jest kultura wizualna”, ograniczę się do jednego tylko, bardzo zresztą wąskiego, aspektu. Istotnego wszakże z punktu widzenia socjologa. Zwłaszcza socjologa-badacza. $Z$ tej perspektywy kultura wizualna jawi się $\mathrm{w}$ wartościujący, partykularny i utylitarny sposób - jako umiejętność patrzenia (tu: również dosłownie „patrzenia”) na rzeczywistość społeczną. Objaśnię pokrótce, co przez to rozumiem. Otóż to, co bywa nagminnym grzechem popełnianym przez wielu kolegów po fachu, to praktyka opisywania świata „zza biurka”. W konsekwencji takiej praktyki — petryfikacja utrwalonego obrazu rzeczywistości. Obrazu, który jest jedynie platońskim cieniem zdarzeń dziejących się „tuż za oknem” gabinetu naukowca. Tymczasem to, co powinno cechować rzetelnego badacza, to intensywne i uważne przyglądanie się wielu światom społecznym w bezpośrednim $z$ nimi kontakcie. Spójrzmy na przykład na badania świata organizacji biznesowych. Póki nie znajdę się we wnętrzu firmy i nie odwiedzę wszystkich oficjalnych i nieoficjalnych przestrzeni, w których pracują członkowie organizacji, póki nie zobaczę, jak wygląda gabinet prezesa, co znajduje się na jego biurku i jakie dyplomy wiszą za jego plecami, jakie kalendarze wieszają w swych kantorkach majstrowie i robotnicy, nie zarejestruję, w co ubierają się pracownicy biura w tak zwany 
casual day itd., póty niczego pew ne go nie będę mógł powiedzieć na temat wartości, norm, symboliki i praktyk interakcyjnych charakterystycznych dla danej organizacji. Dopiero zauważone i utrwalone na różnego rodzaju nośnikach artefakty, tak samo przecież ważne jak usłyszane narracje i opowieści aktorów społecznych, dadzą mi podstawę do formułowania jakichkolwiek wniosków na temat danego świata społecznego i jego kultury.

Pytania, „czy” i „po co” badać kulturę wizualną, nie wymagają w zasadzie uzasadnienia. To tak jakby zapytać, czy i po co badać kulturę w ogóle. Ta bowiem jest niepodzielna. Dzieła sztuki wypełniające muzea, zdjęcia gwiazd pop w pokojach nastolatek, billboardy z reklamami sieci komórkowych, albumy rodzinne, filmy propagandowe i miliony innych artefaktów tworzonych w różnych celach i przy użyciu różnych środków mówią w zasadzie zawsze o tym samym: o ludzkim świecie wartości i motywów działań. O naszych obawach i pragnieniach, codziennych problemach i zasadniczych dylematach egzystencjalnych. Są nie tylko formą lub wyrazem kultury, ale przede wszystkim samą kulturą. Dla socjologa, zwłaszcza badacza życia społecznego i różnorakich jego przejawów, pytania postawione na wstępie mają retoryczny charakter. Trzeba jedynie — i aż — umieć dostrzegać „rzeczy w świecie”, patrzeć intensywnie i uważnie.

Ciekawszym problemem jest wybór metody lub sposobu analizy, a przede wszystkim określenie statusu obrazów w relacji do innego rodzaju danych. Stoję na stanowisku, że nie ma $\mathrm{w}$ tym względzie nienaruszalnych reguł. W zależności od celów i przedmiotu badań zdjęcia, filmy lub inne artefakty mogą stanowić jedyne, główne, równorzędne $z$ innymi lub uzupełniające źródło danych. Oczywiście, same w sobie (np. proces ich tworzenia, odbioru, różnorakich użyć) mogą być tematem badania. W sumie, metody i sposoby analizy winny być podporządkowane zainteresowaniom i celom, jakie stawia sobie badacz. Chodzi o to, by pies machał ogonem, nie odwrotnie. Uwaga ta odnosi się, rzecz jasna, do każdego rodzaju danych, nie tylko wizualnych.

Obrazy mogą być użyte nie tylko w różnych celach, ale też na różnych etapach badania. Na przykład we wstępnej fazie mogą stanowić swoisty katalizator narracji i różnorakich wypowiedzi uczestników badania. W każdym momencie mogą być środkiem, za pomocą którego informatorzy wrażają swe emocje, wrażenia, stany umysłu i snują opowieści o świecie. Mogą wreszcie być użyte jako forma komentarza czy podsumowania przeprowadzonych analiz.

Warto zaznaczyć, że w wielu realnych sytuacjach badawczych krytycznym momentem będzie kwestia zapisu wrażeń i impresji, jakich pod wpływem obrazów doznaje badacz i/lub jego partnerzy. Potrzeba ujmowania wspomnianych (widzianych i przeżywanych) fenomenów przy użyciu języka mówionego, a dalej jego transkrypcji, stwarza problem a dekwat no ści owego przekładu. $\mathrm{Z}$ jednej strony więc nacisk winien być kładziony na opracowywanie specyficznych metod zapisu i kodowania (a dalej analizy) danych wizualnych, $z$ drugiej zaś - atrakcyjne wydaje się śledzenie sposobów, za pomocą których aktorzy społeczni u zgadniają to „co widzą" i „co to znaczy”. Jak konstru- 
owany i integrowany we względnie koherentną całość jest „świat obrazów” (także światy „dźwięków”, „zapachów”, „smaków”) i „świat słów”.

TOMASZ FERENC

Katedra Socjologii Sztuki

Instytut Socjologii

Uniwersytet Łódzki

W najszerszym rozumieniu pojęciem „kultura wizualna” opisujemy wszystkie zjawiska o charakterze kulturowym, które posiadają swoje wizualne manifestacje. Kultura wizualna oznaczać będzie zatem zespół wszelkich obiektów wytwarzanych przez człowieka, powstających we wszystkich możliwych technikach, przy wykorzystaniu różnorodnych materiałów i nośników, i spełniających rozmaite funkcje. Wizualne spektrum obejmuje zatem wszystko to, co możemy objąć percepcją wzrokową (między innymi architekturę, modę, design, formy przemysłowe oraz wszelkiego typu obrazy). Elementem tak szeroko rozumianej kultury wizualnej jest ikonosfera, która zgodne ze swoim źródłosłowem oznacza sferę kulturowo wytwarzanych obrazów. To właśnie ta sfera bardzo często utożsamiana jest $z$ kulturą wizualną, choć stanowi jedynie jej fragment - kulturę obrazu.

Składają się na nią obrazy tworzone metodami „tradycyjnymi” (manualnymi) oraz "mechanicznymi” (obrazy wytwarzane za pomocą urządzeń/aparatów). Te ostatnie przybierają formę zapisu analogowego lub cyfrowego. Kultura wizualna stanowiąca zbiór wszelkich przedstawień i form wizualnych ma charakter kumulatywny i zmienny. Składające się na nią elementy podlegają nieustannym transformacjom oraz redefinicjom.

Co zaś tyczy się konieczności badania kultury wizualnej, to można ją uzasadniać na kilka sposobów. Wszelkie wizualne formy stanowią istotny, jeśli nie fundamentalny, składnik współczesnej kultury. Już sama ich powszechność uzasadnia konieczność pogłębionego studiowania kultury wizualnej, w kontekście badań nad kulturą symboliczną. Jednym z podstawowych zadań powinna być próba nieustannego ustalania znaczenia tego, co wizualne, i tego, jak zmienia się obecność i rola wizualności w życiu społecznym. Rozmaite przejawy kultury wizualnej mają charakter regulatywny (często także opresyjny i manipulacyjny), istotnie wpływając na szeroko rozumiane życie społeczne. Poznanie różnych form oddziaływania sfery wizualnej na zachowania społeczne wydaje się jednym z kluczowych problemów badawczych. Badanie kultury wizualnej powinno obejmować zatem wszelkie przejawy wizualności, przy uwzględnieniu każdej możliwej perspektywy badawczej. Nie ulega wątpliwości to, że studia te muszą mieć charakter interdyscyplinarny, począwszy od filozofii, estetyki, historii, historii sztuki, socjologii, antropologii, psychologii, a na ekonomi koń- 
cząc. Konieczna jest także precyzyjna metodologia studiowania tej dziedziny kultury. W odniesieniu do ikonosfery - kultury obrazów - istnieje wiele metod prowadzania badań nad tak zwanymi danymi wizualnymi. Teoretycy metod wizualnych zwracają uwagę na wiele możliwych dróg analizowania tego rodzaju danych przez czerpanie inspiracji między innymi z: hermeneutyki, strukturalizmu, interakcjonizmu symbolicznego, etnometodologii, semiologii, antropologii kognitywnej, goffmanowskiej perspektywy dramaturgicznej. W badaniach nad sferą kultury obrazu należy uwzględnić dwoisty charakter każdego przedstawiania. Z jednej strony może być ono nośnikiem informacji (np. malarstwo realistyczne, fotografia, film dokumentalny), $z$ drugiej jest zawsze manifestacją złożonego systemu uwarunkowań ideologicznych, społecznych, kulturowych czy estetycznych. Należy zatem bacznej obserwacji poddać to, w jaki sposób przy wykorzystywaniu wizualności konstruowana jest prawda, naturalność i wiarygodność poszczególnych przedstawień. Przedstawienia wizualne stają się $\mathrm{w}$ tym przypadku jednym $\mathrm{z}$ wielu możliwych przejawów działania reżimów prawdy i strategii perswazyjnych. Obszarem szczególnej badawczej wnikliwości powinny stać się wszelkie instytucje nadające obrazom znaczenia i dominujące $\mathrm{w}$ procesach dystrybuowania przekazów wizualnych. Wreszcie takimi badaniami należy objąć także sferę recepcji obrazów oraz wszelkich prywatnych zastosowań wizualnych technologii.

Reasumując — kulturę wizualną należy poddawać systematycznym, wnikliwym i interdyscyplinarnym badaniom uwzględniającym wielość teoretycznych perspektyw, przy jednoczesnym dążeniu do stworzenia autonomicznej teorii wizualności.

\section{MARIA GOEĘBIEWSKA* \\ Zespót Filozofii Kultury \\ Instytut Filozofii $i$ Socjologii PAN $w$ Warszawie}

Zagadnienie kultury wizualnej to $\mathrm{z}$ pewnością zagadnienie przedstawienia kulturowego, danego nam $w$ przekazach intersubiektywnych, ale również kwestia subiektywnego przedstawienia mentalnego - wglądu wewnętrznego, wyobrażenia czy schematów poznawczych jako obrazów mentalnych. Współczesne pytanie o kulturę wizualną okazuje się dawno już postawionym pytaniem o obraz jako źródło wiedzy i jako przedmiot przeżycia estetycznego. Jest ono uzupełnione współcześnie o zagadnienia poruszane przez antropologię obrazu, między innymi przez Hansa Beltinga. To pytanie antropologiczne zostało również dawno postawione przez myślicieli rozważających zagadnienie

\footnotetext{
* Autorka nadała swojej wypowiedzi tytuł: „Antropologia obrazu i słowniki wizualne” (przyp. red.).
} 
wewnętrznego oglądu jako elementu poznania ludzkiego, jako źródła wiedzy. Związek wewnętrznego oglądu i obrazu wytwarzanego na potrzeby komunikacyjne scharakteryzował między innymi Erwin Panofsky w książce Idea. A Concept in Art Theory ${ }^{1}$. Opisał tam przemiany w rozumieniu pojęcia idei, dokonujące się w kulturze zachodniej, począwszy od Platona (eidos jako obraz wewnętrzny) przez empirystów brytyjskich (idea jako obraz mentalny), a wpływające na sposób obrazowania. W nowożytności łączono obraz wewnętrzny z tym, co idealne, wzorcowe (między innymi wyobraźnia transcendentalna Kanta), ale też rozdzielano obraz od tego, co daje wgląd w prawdę (obraz jako pozór, jako simulacrum). Zapomniany związek obrazu z prawomocną wiedzą, również z wiedzą człowieka o sobie samym (kwestie antropologiczne), próbuje przywrócić szeroko rozumiana antropologia obrazu, którą proponuje Hans Belting. Jego studia, podobnie jak badania Panofsky'ego, wychodzą od zagadnień historii sztuki i nobilitują obraz jako źródło wiedzy i przeżycia (wobec prymatu w tradycji zachodniej tego, co dyskursywne, i wobec tak zwanego kryzysu przedstawienia).

Jak łatwo zauważyć, współczesne przekazy wizualne wymagają szerokiego pojmowania antropologii obrazu jako raczej antropologii wizualności, czyli tego, co jest nam w ogóle dane w percepcji dzięki widzeniu. Przedstawienia kulturowe rozpatrywane w kontekście wizualnego postrzegania to współcześnie już nie tylko malarstwo, rzeźba, fotografia czy film, ale także medyczne wizualizacje ciała ludzkiego oraz cała sfera społecznych praktyk, rozważanych w kategoriach spektaklu lub po prostu jako przedmiot spojrzenia (architektura jako spektakl - Jacques Derrida; krajobraz i widok jako kształtowanie indywidualnego spojrzenia - Vilém Flusser; zmiany w uwarunkowaniach percepcji wizualnej - estetyka prędkości i znikania Paula Virilio; tekst wstępnie postrzegany, widziany jako „figura” - Jean-François Lyotard; procesy zacierania granic między tym, co mówione, pisane i ikoniczne w przekazach internetowych Mike Sandbothe).

Tak szeroko pojęta kultura wizualna i zarazem antropologia wizualności wymaga badania uwarunkowań percepcji, jej kulturowego sposobu kształtowania (patrzeć to nie zawsze widzieć według Flussera), opisu przemian w percepcji, dokonujących się pod wpływem narzędzi technicznych (koncepcja wizjoniki Virilio, wpływ obrazów technicznych i syntetycznych wedle Flussera). Badania te wychodzą od założeń filozoficznych, dotyczących podmiotu poznania i percepcji (fenomenologia i kognitywizm), rozważają relacje między podmiotem i przedmiotem percepcji wizualnej (ulokowanie spojrzenia widza $\mathrm{w}$ obrazie — strukturalizm i psychoanaliza). Są to również badania empiryczne odbioru przekazów (brytyjskie studia kulturowe). $Z$ drugiej strony, przedmiotem antropologii wizualności są kulturowe przedstawienia, analizowane i interpretowane

${ }^{1}$ E. Panofsky, Idea. A Concept in Art Theory: A Study of the Changes in the Definition and Conception of the Term "Idea", from Plato to the $17^{\text {th }}$ Century, when the Modern Definition Emerged, tłum. J. S. Peake, University of South Carolina Press, Columbia 1968. 
zgodnie z różnymi założeniami metodologicznymi, przede wszystkim badania historyczne i semiotyczne.

Można powiedzieć, że podstawowym zadaniem antropologii wizualności, która ma badać szeroko rozumianą kulturę wizualną, okazuje się określenie i opisanie kodów wizualnych czy też słowników ikonicznych pojawiających się współcześnie. Stanowią one po części kontynuację dotychczasowych słowników (malarskich, architektonicznych itd.) i zarazem wprowadzają nowe kodyfikacje, przedmioty przedstawienia, tematykę. Słowniki te i kody, obecne w przekazach kulturowych jako pewne wzorce czy modele, nie do końca uświadamiane, wpływają na kształtowanie percepcji wizualnej. Słowniki wizualne są zatem tym, co pośredniczy między indywidualną percepcją uczestnika kultury wizualnej a jej intersubiektywnymi, danymi w komunikacji przekazami. Wydobyciu takich kodów tekstualnych i ikonicznych poświęcili wiele uwagi Roland Barthes, Michel Foucault, ale też inni badacze zajmujący się semiotyką tekstu i obrazu.

Badania te rozwijają twórcy ideologicznej analizy przekazu, przede wszystkim Arthur Asa Berger. Analiza ta łączy dotychczasowe metodologie badań przekazów kultury i uwzględnia zagadnienie odbioru. Przedmiotem analizy są znaczenia obecne $\mathrm{w}$ przekazach, a celem charakterystyka ich relacji z kontekstami dominującymi, które wpływają na kształtowanie słowników czy kodów (kontekst historyczny, światopoglądowy i estetyczny bieżących wydarzeń, do których odnoszą się komunikaty). Przyjmuje się tu fenomenologiczne założenie dotyczące konstytucji znaczenia, ale znaczenie (reprezentację mentalną i kulturowa) ujmuje się za poststrukturalistami jako zawsze zindywidualizowane jednostkowo, społecznie, kulturowo. Analiza ta bada warunki zróżnicowania znaczeń w przekazach kultury (indywidualny światopogląd i historia jednostkowa - odwołania do psychoanalizy). Wskazuje grupy odbiorców znaczeń i zarazem pozwala prześledzić kształtowanie się słowników czy kodów, do których odwołują się oni w swoich praktykach wytwórczych i odbiorczych. Należałoby więc gromadzić i porządkować dotychczasowe obrazy dzięki cyfrowej technologii (Lev Manovich), aby następnie poszukiwać ich wewnętrznej kodyfikacji, która wpływa nie tylko na ich ogląd, ale dzięki nim na nasz ogląd otoczenia, nas samych i na nasze poglądy.

\section{MARYLA HOPFINGER}

Instytut Badań Literackich PAN w Warszawie

„Kultura wizualna” - pojęcie to, w moim rozumieniu, wiąże się z percepcją wzrokową i dotyczy rozmaitych wizualnych aspektów i wymiarów realności, jak też związanych z komunikacją pośrednią wizualnych utrwaleń na różnych nośnikach. Obejmuję tym pojęciem między innymi postrzegane w kontakcie 
bezpośrednim środowisko naturalne, przestrzeń miejską, zachowania niewerbalne, wnętrza czy ubiory oraz przedstawienia obrazowe (rysunki, malarstwo, grafika, fotografia i in.), zapisy alfabetyczne (rękopiśmienne, druki, pismo elektroniczne), wizualny wymiar filmu, telewizji, internetu. To wyliczenie nie jest kompletne. Pozwala mi jednak na stwierdzenie, że kultura wizualna występuje we wszystkich epokach, niezależnie od kryterium ich wyodrębnienia. I może być na przykład rekonstruowana zarówno w odniesieniu do epoki oralnej czy opartej na piśmie i druku, jak i do czasów współczesnych.

Szczególnie żywe dzisiaj zainteresowanie kulturą wizualną jest, jak myślę, najzupełniej uzasadnione. Wynika $z$ „inwazji obrazu”, która dzięki rozpowszechnionym technikom utrwalenia i przekazu zmieniła zasadniczo nasze doświadczenia. Na tę zmianę złożyło się bogactwo i różnorodność przekazów wizualnych, komplikacje znaczeniowe obrazów, ich ważny udział w budowaniu znaczeń, a przez to kulturowa nobilitacja. Tradycyjnie znaczenie przede wszystkim przypisywano słowom, językowi, zwłaszcza pisanemu. Ale właściwie cały XX wiek dostarcza przykładów rosnącej roli znaczeniowej i kulturowej obrazu (z jednej strony malarstwo abstrakcyjne, $z$ drugiej fotografia), który nie tylko przedstawia - i niekoniecznie przedstawia — lecz także znaczy. Nadto przykładów, że słow o nie tylko znaczy, lecz także przedstawia (zwłaszcza poezja konkretna czy liberatura).

Natomiast określenie „kultura wizualna” nie wydaje mi się trafne jako diagnoza współczesności. Nie uwzględnia bowiem innych przemian decydujących w moim przekonaniu o współczesnym typie kultury. Pomija uderzający awans audialności oraz - co uważam za najważniejsze - audiowizualny (multimedialny) charakter dominujących dzisiaj przekazów, analogowych i digitalnych.

Nie kwestionuję w żadnym razie celowości badania dzisiaj kultury wizualnej. Uważam jedynie, że uwzględnianie jednego tylko wymiaru współczesności nie może stać się diagnozą całej kultury.

\section{KRZYSZTOF JURECKI}

Wyższa Szkota Sztuki i Projektowania w Łodzi

Akademia Sztuk Pięknych w Gdańsku

Kultura wizualna to całość modernizacyjnych przekształceń związanych z przemianami cywilizacyjnymi, obyczajowymi i kulturowymi, które zapisywane są między innymi przez media technologiczne, jak fotografia czy film, przez uczestników tego życia, czasami spektaklu. Kultura wizualna jest domeną nie tylko artystów, ale świadomego lub nieświadomego społeczeństwa, które dokumentuje i zapisuje swe przemiany i otoczenie swego świata. Powstaje nowy rodzaj kultury, przede wszystkim miejskiej, wraz z oddziaływaniem reklamy, w której mamy do czynienia przede wszystkim z wpływem kultury ni- 
skiej i zanikiem jakości symbolicznej powstałego obrazu na rzecz genderowej, ale $z$ niespotykaną estetyzacją przedstawianej rzeczywistości. Kultura wizualna może analizować, badać i diagnozować przyszły rozwój kulturowy w tak powstałej przestrzeni artystycznej, choć przekraczającej ramy dawnego obszaru sztuki.

Czy badać kulturę wizualną? Tak, jak najbardziej. Należy poszukiwać zarówno narzędzi służących do badań, jak odszukiwać i przedstawiać najciekawsze zapisy, dokonania czy może nawet najwartościowsze projekty z tak powstałego obrazu społeczeństwa. Dla mnie, jako historyka sztuki i fotografii, najbardziej atrakcyjne są takie formy, które odnoszą się do tradycji kultury symbolicznej, wyższej, lub świadomie łączące dokonania high art z low art, co stało się usankcjonowaniem dokonań amerykańskiego pop artu już w latach sześćdziesiątych XX wieku. Oczywiście, w obszarze kultury wizualnej, oprócz świadomości kulturowej, a przede wszystkim artystycznej, istotna jest też intuicja twórcza. Kultura wizualna zdecydowanie bardziej otwarta jest na amatorów, pasjonatów, nie tylko świadomych swej profesji twórców, którzy w tym zakresie mogą manipulować znakami lub poszukiwać nowych, jak twórcy tak zwanego street art.

JERZY KACZMAREK

Zaktad Historii Socjologii

Instytut Socjologii

Uniwersytet im. Adama Mickiewicza w Poznaniu

Wydaje mi się, że pojęcie „kultura wizualna” najlepiej tłumaczyć literalnie, a więc jako pewną specyficzną odmianę kultury, czyli tego, co wytworzył człowiek, a co nie jest naturą. Socjolog wizualny dodałby oczywiście istotną uwagę o tym, że owe wytwory muszą funkcjonować w świadomości społecznej, muszą mieć wymiar grupowy. Czym jednak są te wytwory? Przede wszystkim odbiciem rzeczywistości, jej emanacją w sferze wizualnej. Są również formą zabawy. Oczywiście, są także komunikatami. Mają jeszcze jedno, ważne znaczenie - otóż są swoistą formą magazynowania pamięci, jej przekazywania oraz interpretacji. Tak dzieje się często chociażby w wywiadach wspomaganych fotografiami. Jeden ze współczesnych niemieckich poetów - Jochen Kelter - w wierszu „Fotografie Zoli” opisuje stare fotografie: ludzi, tramwaje, ulice $\mathrm{w}$ deszczu, dzieci w marynarskich ubrankach. Zakończenie utworu jest wstrząsające: „nikt nie przeżył”. A jednak przecież przeżyły fotografie, na które możemy patrzeć, które możemy analizować, interpretować. To jest właśnie między innymi kultura wizualna: stare, pożółkłe zdjęcia trzymane w sfatygowanym portfelu. Zresztą i sam portfel też do niej należy. Ślady blizn na nim, tłuste plamy i przypalone papierosem miejsca. 
Pytanie o to, czy i po co badać kulturę wizualną, jest prowokacyjne. Skoro coś istnieje, już jest wystarczającym powodem, by stało się obiektem naukowego zainteresowania. Cele owych badań mogą być dwojakie: poznanie samo w sobie bądź chęć praktycznego wykorzystania ich wyników. Oba te zamierzenia pojawiają się w badaniach kultury wizualnej. To pierwsze w oczywisty sposób, drugie zaś chociażby w coraz częstszej współpracy badaczy akademickich zajmujących się wizualnością z przedstawicielami komercyjnych firm marketingowych. Płaszczyzną takiego spotkania i wzajemnej inspiracji była na przykład sesja poświęcona socjologii wizualnej podczas XIII Ogólnopolskiego Zjazdu Socjologicznego w Zielonej Górze, który odbył się we wrześniu 2007 r. Powodem zainteresowania się naukowców wizualnością jest oczywiście coraz większe jej znaczenie w świecie współczesnym. Już Herbert Spencer stwierdził, że w procesie ewolucji społecznej czynniki pierwotne, a więc związane ze środowiskiem naturalnym i cielesnością człowieka, odgrywają coraz mniejszą rolę, a czynniki wtórne, czyli ogólnie mówiąc „kultura”, mają coraz większe znaczenie. Zatem również kultura wizualna w miarę rozwoju cywilizacji odgrywa coraz większą rolę w życiu pojedynczego człowieka, poszczególnych grup społecznych i całych społeczeństw. Wystarczy rozejrzeć się dookoła siebie, gdy idziemy ulicą, by zostać przytłoczonym wielością wizualnych wyobrażeń — od tych „oficjalnych” po „niewidzialne miasto” ${ }^{1}$. To tylko wybrane hasła, które można rozwinąć w bardzo długi kwestionariusz współczesnych aspektów wizualności. Do tego dochodzą jeszcze, tak charakterystyczne dziś, obrazy wirtualne. Interesujące będzie zatem pytanie, czy w naszych czasach bardziej zaczynamy myśleć obrazami aniżeli słowami? Czy trzeba zmodyfikować pewne koncepcje wypracowane na obszarze socjologii języka? To również jedna $z$ interesujących kwestii, którą powinni zająć się badacze kultury wizualnej.

No i wreszcie pytanie, chyba najtrudniejsze, jak badać kulturę wizualną? Przede wszystkim w sposób interdyscyplinarny, obejmujący nie tylko nauki humanistyczne, ale również przyrodnicze (tutaj tak ważne chociażby badania nad reakcjami ludzkiego ciała na obrazy). Poza tym trzeba ciągle wypracowywać metody analizy obrazów, które w socjologii wizualnej i dziedzinach jej pokrewnych nie są jeszcze w pełni rozwinięte. Jest oczywiście semiologia, są metody przejęte $z$ historii sztuki, zaczyna się używać teorii ugruntowanej $\mathrm{w}$ badaniu wizualności, są różne zastosowania teorii krytycznej. Można jeszcze dorzucić kilka innych metod i technik, problem w tym, aby z tego, dość chaotycznego zbioru stworzyć dopełniającą się całość. Bardzo interesującym aspektem badań jest używanie przez badaczy obrazów do wypowiedzi naukowej. Coraz częściej

\footnotetext{
${ }^{1}$ Autor odwołuje się tutaj do ogólnopolskiego projektu badawczego, w którym socjolodzy, antropolodzy i fotografowie starają się dokumentować i analizować przejawy oddolnej kreatywności mieszkańców największych polskich miast, polegającej na różnego rodzaju interwencjach mających na celu dostosowanie miejskich przestrzeni do ich pragnień i potrzeb; adres internetowej bazy zdjęć: www.niewidzialnemiasto.pl (przyp. red.).
} 
zaczynają pojawiać się takie formy wypowiedzi, jak fotoeseje czy film socjologiczny, którego poprzednikiem był film etnograficzny. Na doskonalenie tych form również trzeba zwrócić uwagę.

KRZYSZTOF TOMASZ KONECKI

Katedra Socjologii Organizacji i Zarzadzania

Instytut Socjologii

Uniwersytet Łódzki

Kultura wizualna może być potraktowana jako nasze otoczenie, które jest wytworzone przez człowieka w określony sposób dla oglądania oraz, w konsekwencji, w określony sposób percypowane. Ta „określoność” czy „specyficzność" wynika z celów zarówno wytwarzania przez człowieka tego otoczenia, jak i pewnych modalności percepcji dostarczonych przez tradycję i przekazywanych w trakcie socjalizacji. Wszystko, co jest przeznaczone do oglądania, należy do kultury wizualnej. Jednak jej konkretna treść jest zależna od definicji, jakie nakładają na postrzegane obiekty jednostki, często dzieje się to w trakcie konwersacji $z$ innymi lub z samym soba. Kultura wizualna ma charakter interakcyjny. Nie istnieje bez Innego, który podsuwa nam „ramy” obrazu i wobec którego postrzeżony obiekt może być pokazany, zinterpretowany i najczęściej zaświadczony przez mowę. Percepcja obiektu jest „omówiona społecznie", zanim stanie się naocznością, daną nam tu i teraz.

To jest uwarunkowanie społeczno-kulturowe tego, co widzimy i co możemy widzieć. Czasami możemy zobaczyć więcej niż kultura nam umożliwiła poprzez swoje schematy, wiedzę i język werbalny, który wydaje nam się ostateczną instancją umożliwiającą zaświadczenie tego, co widzimy. Czasami widzimy jednak więcej, niż jesteśmy w stanie o tym powiedzieć za pomocą języka werbalnego, lub też czasami nie ma takiej potrzeby, by się nim posługiwać, by przekazywać określone znaczenia. Kultura wizualna ma charakter interakcyjny, ale niekoniecznie werbalny. Lingwistyczne symbole pozwalają nam przekazywać znaczenia i nadbudowywać nad nimi inne znaczenia lub poziom znaczeń. Jednak w interakcji, w konkretnym kontekście, widzenie buduje wzajemne zrozumienie często bez słów. Umożliwiają nam to g e sty. Gesty te to: spojrzenia wprost, ukradkowe spojrzenia, wpatrywanie się, „wzrokowe ignorowanie innego", i różne gesty niewerbalne naszego ciała. Gesty tu i teraz są często przekształceniami gestów i ich choreograficznych schematów zdefiniowanych kulturowo. Sama kultura, w tym wizualna, bez jej uaktywnienia w interakcji nie zaistnieje. A większość naszych komunikatów w interakcji jest opatrzona komentarzem niewerbalnym. Patrzenie w sensie fizycznym także należy do kultury wizualnej, podobnie jak „niepatrzenie” czy niewidzenie pewnych obiektów, zachowań itd. To właśnie w kontekstach interakcyjnych dopełniamy to, co podają nam względnie stałe schematy postrzeżeniowe. Interakcja jest tak dyna- 
miczna, że kultura wizualna przekształca się, modyfikuje i jest zwykle osiągana poprzez praktyki oglądania tu i teraz.

To, co jest kulturą wizualną, to także s posoby patrzenia na określone obiekty w określonych kontekstach. Schemat jest niewystarczający, by dobrze widzieć. By podziwiać piękny krajobraz, na przykład widok na Zatokę San Francisco, nie wystarczy mi znajomość schematu, znajomość zarysu obiektów do postrzegania i ich układ. Muszę podziw i interpretację piękna dopełnić interakcją, a najczęściej praktyką fotograficznego uwieczniania tej interpretacji. Podziwiam dany obiekt ze względu na coś, dla kogoś, z powodu czegoś, mając na uwadze innych, którzy podziwiali lub będą podziwiać. Nie mogę pominąc podziwu innych i ich definicji piękna krajobrazu. Nie mogę widzieć obiektu bezpośrednio, bo nic bym wtedy nie widział. Byłbym ślepym kulturowo w wymiarze wizualnym. Te interakcyjne uwarunkowania dotyczą dialogu, który toczymy nad widzialnym pięknem, przyrodą czy widzialnymi obiektami fizycznymi. Bezpośredni ogląd wyklucza interakcję, wyklucza wpływ społeczny i tym samym możliwość zakomunikowania innym, co widziałem i co warte było zobaczenia. Widzenie zatem ściśle wiąże się z wartościowaniem. Jest $z$ gruntu czynnością kulturową. Oczywistą sprawą jest wpływ interakcji na oglądanie, gdy mamy bezpośrednio obok siebie partnerów interakcji, którzy wpływają na to, co widzę i co mogę widzieć, poprzez swoje komentarze, perswazję, podawanie w wątpliwość kulturowych definicji piękna krajobrazu, dostarczanie swojej wizji piękna natury itp.

Uwzględniając praktyki organizowania widzenia określonych obiektów, badamy tak naprawdę subkultury widzenia, ponieważ praktyki te związane są ściśle $z$ określonymi kontekstami. Interakcje i ich konteksty są niewyczerpalnym źródłem tworzenia praktyk widzenia. Obserwując, jak ludzie widzą rzeczywistość, badamy, jak tworzą określone sposoby widzenia i oglądania obiektów. Sami jako obserwatorzy i badacze jesteśmy elementem pewnej „subkultury oglądania" innych, którzy coś widzą i także, tak jak my, oglądają. Nasze metody obserwacji (obserwacja naoczna, fotografie, nagrania wideo i wywiady im towarzyszące, rysowanie obiektów itp.) są praktykami oglądania, które niedaleko odbiegły od potocznych praktyk, których używają uczestnicy życia codziennego. „Podglądnie” jest esencją socjologii. Socjologia wizualna pokazuje to tylko bardziej naocznie niż socjologia sondażowa. Nasze praktyki organizowania oglądania powinny brać pod uwagę to, jak badani ludzie oglądają i organizują sobie narzędzia i sposoby widzenia rzeczywistości. Jeśli jest ona oglądana głównie przez telewizję, to powinniśmy zobaczyć, jak praktyka oglądania telewizji jest organizowana przez nich: kto i z kim ogląda telewizję, czy telewizja jest głównym źródłem informacji i kryteriów oceny natury i przyrody (schematy widzenia), jaki jest telewizor, gdzie umieszczony (kontekst przestrzenny), jak organizuje się z nim życie codzienne (spożywanie posiłków, prasowanie, gotowanie, kochanie się, sprzątanie itp.), reakcje emocjonalne na przekazywane wydarzenie (gesty emocjonalne), interakcje werbalne $z$ telewi- 
zorem (okrzyki, wypowiedzi, „rozmowy” z telewizorem) itp. Badacz powinien spojrzeć na to, jak ludzie widzą rzeczywistość, $z$ ich punktu widzenia, poprzez obrazy, które są im najbliższe.

Interakcje pełne są komunikacji niewerbalnej podającej wskazówki odnośnie do rozumienia sytuacji, która jest postrzegana i oglądana. Aby można było zbadać tego typu interakcje, muszą być one również obrazowo zatrzymane i oglądane, a patrzenie musi być także zobaczone przez badacza, by mogło być przez niego zanalizowane i zaświadczone jakimś raportem (być może obrazowo-słownym) rozumienia danej sytuacji. Jest to drugi poziom widzenia i oglądania. Szczegółowa analiza interakcji (nagranej na wideo lub sfotografowanej w sekwencji jakiegoś działania) pozwala nam zobaczyć, jak praktyki oglądania są konstruowane w interakcji na poziomie subtelnych gestów, „minimalnych spojrzeń” lub „niepatrzenia” oraz posługiwania się narzędziami tworzenia obrazów.

Wizualność jest elementem życia codziennego. Aby zrozumieć wiele aspektów naszego działania $\mathrm{w}$ życiu codziennym, należy podjąć badanie tego, jak działania są konstruowane poprzez praktyki tworzenia obrazów, widzenia i oglądania oraz używania obrazów? Praktyki te budują ostatecznie określone procesy wizualizacji. Konteksty życia codziennego z ich praktykami wizualnymi tworzą wspomniane subkultury wizualne. Przykładowe konteksty generujące określone subkultury wizualne to: konteksty oglądania i podziwiania krajobrazów (proces wizualizacji piękna przyrody), konteksty oglądania i widzenia osób wykluczonych społecznie (proces wizualizacji wykluczenia społecznego, na przykład proces wizualizacji bezdomności), konteksty kreujące wizualność ułomności (proces wizualizacji upośledzenia fizycznego i/lub umysłowego), konteksty przedstawień religijnych (wizualizacja procesów religijnych, na przykład wizualizacja procesu objawienia, oświecenia czy przepowiedni), konteksty argumentacji naukowych (proces wizualizacji dowodu naukowego) itp. Konteksty te wpływają na tworzenie określonych subkultur wizualnych, których zbadanie jest niezbędne, by w ogóle rozumieć jakiekolwiek subkultury. „Światy życia”, w których przebywamy, są odczuwane za pomocą zmysłów, w tym zmysłu wzroku. Zmysł wzroku, ukształtowany w określony sposób również przez kulturę, jest wykorzystany przez jednostkę $\mathrm{w}$ interakcjach $\mathrm{z}$ innymi $\mathrm{w}$ określonych kontekstach do przedstawiania, ale także do widzenia oraz oglądania określonych przedstawień. Bez zbadania i analizy praktyk budujących proces widzenia i oglądania, a w konsekwencji także procesów wizualizacji obiektów, tematów i problemów, czyli przedstawiania ich $\mathrm{w}$ formie obrazu/obrazów, niemożliwe jest budowanie w socjologii sensownego modelu wyjaśniającego. Badanie subkultur wizualnych obejmowałoby zatem badanie konkretnych praktyk budowania obrazów, praktyk oglądania i widzenia, badanie struktur i wbudowanych w nie treści obrazów, praktyki używania obrazów oraz konsekwencji przedstawiania określonych obiektów, tematów i problemów. Elementy te powinny być badane 
w wymiarze interakcyjnym, w którym „patrzenie i obraz” przedstawienia czegoś to nieodzowny element budowania definicji sytuacji, a także działań zbiorowych. Subkultury rodzinne, organizacyjne, subkultury wspólnot religijnych, wspólnot młodzieżowych zarówno nie składają się z „niewidzialnych” omówień samych aktorów je tworzących, jak i nie są tylko objaśnieniami motywów, racjonalizacji i słownych opisów działań, ale są samymi praktykami tworzenia widzialności i obrazów oraz konsekwencją tych praktyk. Nagrywanie na wideo, fotografowanie, rysowanie, tatuowanie, konstruowanie emblematów i ozdób, ubiór, tworzenie określonej przestrzeni i wystroju wnętrz dla określonych działań itp. - wszystko to składa się na subkultury wizualne, które manifestują się w konkretnych miejscach i czasie. Subkultura wizualna jest określonym dzianiem się konstrukcji obrazu, przygotowywania do oglądania i patrzenia, prezentacji obrazu i jego praktycznego użycia oraz możliwą próbą kontrolowania odbioru obrazu. Pytać, po co badać subkultury wizualne, to podobnie jak pytać, po co patrzeć i oglądać, skoro można wszystko słownie opowiedzieć.

MAREK KRAJEWSKI

Zakład Badań Kultury Wizualnej i Materialnej

Instytut Socjologii

Uniwersytet im. Adama Mickiewicza w Poznaniu

„Kultura wizualna” to wszystko, co może zostać zobaczone przez członków określonej społeczności ${ }^{1}$. Termin ten odnosi się więc do tych $z$ naszych doświadczeń wizualnych, które zostały społecznie uregulowane przez zdefiniowanie, co jest w ogóle możliwe do zobaczenia, przez dostarczenie poznawczych środków kategoryzacji tego, co staje przed naszymi oczami i przez określenie na co, kto i w jaki sposób może patrzeć oraz co powinien wówczas on/ona widzieć. To, co może zostać zobaczone, jest również dookreślone przez taką rekonstrukcję środowiska naszego życia, której skutkiem jest uwidzialnienie niektórych dostępnych wzrokowi bodźców, ukrycie zaś innych. Kulturę wizualną buduje także zbrojenie oka i wyposażanie maszyn w zdolność do patrzenia i analizy obrazu, które nie tylko ogromnie poszerzają zakres tego, co możemy dostrzec, ale też zmieniają sposób, w jaki traktujemy codzienne doświadczenia wizualne wyprodukowane przez nasz aparat wzrokowy ${ }^{2}$. Kultura wizualna to więc przede wszystkim wyregulowanie spojrzeń w taki sposób, że świat stojący przed naszymi oczami wydaje się oczywisty, a nasze działania $\mathrm{w}$ jego obrębie oraz współdziałanie $z$ innymi tę oczywistość potwierdzają.

${ }^{1}$ N. Mirzoeff (red.), Visual Culture: Reader, Routledge, London-New York 2002; zob też L. Cartwright, M. Sturken, Practices of Looking: An Introduction to Visual Culture, Oxford University Press, London-New York 2001.

$2 \mathrm{Na}$ temat społecznej regulacji zmysłowego doświadczania rzeczywistości zob. M. Krajewski, Aromatyzacja bezwonnej kultury, „Kultura i Społeczeństwo” 2002, nr 1; P. Macnaghten, J. Urry, Alternatywne przyrody. Nowe myślenie o przyrodzie i spoteczeństwie, tłum. B. Baran, Scholar, Warszawa 2005. 
Kultura wizualna, jak każda kultura, jest przede wszystkim środkiem adaptacji do środowiska, a więc narzędziem umożliwiającym zastąpienie doświadczeń, których źródłem jest nasz aparat sensoryczny i nasza indywidualna konstytucja, przez te będące produktem regulacji i dające nam poczucie życia we wspólnym świecie. Kultura wizualna ma więc nie tylko sprawić, iż patrząc na to samo będziemy widzieć to samo, ale też doprowadzić do sytuacji, w której wzrok każdego z członków określonej społeczności będzie koncentrował się na wybranych aspektach pola percepcyjnego i ignorował inne. Takie zdefiniowanie kultury wizualnej tożsame jest z przyjęciem, iż jest ona zawsze czyjaś, a więc zarówno odzwierciedla sposób postrzegania rzeczywistości przez określoną wspólnotę, jak i go reguluje.

Oczywiście, błędem byłoby, gdybyśmy zredukowali rolę kultury wizualnej do procesów regulacji postrzegania rzeczywistości (chociaż taka redukcja nie oznaczałaby umniejszenia jej fundamentalnego znaczenia w budowaniu społecznego świata), ponieważ jest ona również jednym z najważniejszych czynników więziotwórczych. To, w jaki sposób widzimy świat i innych, buduje, wyraża i utrwala zawsze nasze relacje $z$ nimi, a nasze kulturowo przepracowane doświadczenia wizualne odpowiedzialne są zarówno za to, kim jesteśmy sami dla siebie, jak i kim są dla nas inni. Kultura wizualna łączy i dzieli, bo wzrokowe doświadczanie rzeczywistości nie jest nigdy neutralne aksjologicznie, ale zawsze pociąga za sobą określone formy wartościowania, zobowiązania moralne, uczucia i emocje ${ }^{3}$.

„Kultura wizualna”, czyli pojęcie, które na stałe zagościło w słowniku humanistyki w ostatnich latach ${ }^{4}$, odegrało bardzo ważną rolę $\mathrm{w}$ definiowaniu przedmiotu visual studies i wypracowaniu ich instytucjonalnej odrębności, ale jego najważniejszą funkcją było zwrócenie uwagi na to, że życie społeczne zakorzenione jest $\mathrm{w}$ procesach zmysłowego doświadczania rzeczywistości i nie można go zrozumieć czy badać bez uwzględnienia roli i znaczenia tego, co wizualne. Dzięki kategorii „kultura wizualna” dostrzegliśmy najpierw, że teksty to również obrazy, a następnie, że obrazy to nie tylko media przenoszące znaczenia, ale też bodźce, dystraktory ${ }^{5}$, przedmioty ${ }^{6}$ czy wtórni agenci (secondary

3 S. Sontag, Regarding the Pain of Others, Picador, New York 2003.

${ }^{4}$ A. Zeidler-Janiszewska, Visual Culture Studies czy antropologicznie zorientowana Bildwissenschaft? O kierunkach zwrotu ikonicznego w naukach o kulturze, „Teksty Drugie” 2006, nr 4; W. J. T. Mitchell, Pokazujac widzenie: krytyka kultury wizualnej (tłum. M. Bryl) oraz N. Mierzoeff, Podmiot kultury wizualnej (tłum. M. Bryl), w: P. Piotrowski, W. Suchocki (red.), „Artium Quaestiones” XVII, Wydawnictwo Naukowe UAM, Poznań 2006.

5 J. Crary, Suspension of Perception: Attention, Spectacle and Modern Culture, MIT Press, Cambridge 2000; G. Franck, The Economy of Attention ( http://www.heise.de/tp/r4/artikel/5/5567/1.html).

${ }^{6}$ E. Williams, J. Hart, Photographs as Objects, w: E. Williams, J. Harts (red.), Photographs, Objects, Histories: On the Materiality of Images, Routledge, London-New York 2004; M. Krajewski, Fotografie jako przedmioty, w: J. Kaczmarek (red.), Do zobaczenia. Socjologia wizualna $w$ praktyce badawczej, Wydawnictwo Naukowe UAM, Poznań 2008, s. 119-132; S. Lash, C. Lury, Global Culture Industry, Polity Press, Cambridge 2007. 
agents) ${ }^{7}$, a także że ich oddziaływanie nie polega tylko na zaproszeniu nas do interpretacji wizualnego przedstawienia, ale też na tym, że wyzwalają one działania, emocje, że zmuszają lub zachęcają nas do zrobienia czegoś, czego bez ich obecności nigdy byśmy nie zrobili ${ }^{8}$.

Kategoria „kultura wizualna” jest jednak pojęciem tyleż pożytecznym, co niebezpiecznym, ponieważ unieobecnia, jako potencjalny przedmiot humanistycznej refleksji i badań, ogromną część naszych doświadczeń wizualnych. Podobnie jak dawniej historia sztuki i estetyka zredukowały wizualność do obrazów wytwarzanych przez artystów i tych sposobów ich odbioru, które preferowała akademia i klasy wyższe ${ }^{9}$, tak visual studies posługujące się kategorią „kultura wizualna” ograniczają to, co widzialne, do tych aspektów naszego pola percepcyjnego czy wyobraźni, które są społecznie uregulowane. Nieprzypadkowo więc kultura wizualna była analizowana przede wszystkim w kontekście procesów modernizacyjnych (a więc jako narzędzie budowania zachodniego, nowoczesnego ładu) ${ }^{10}$, jako środek sprawowania władzy i źródło społecznego wykluczenia oraz stygmatyzacji ${ }^{11}$, jako medium uwodzenia ${ }^{12}$ i środek kontroli procesów tożsamościowych itd. Co więcej, i z pewnością dlatego, by podnieść społeczną doniosłość refleksji nad tym, co wizualne, badania nad nią zostały zredukowane do roli środka, który ma na celu emancypację spod jej władzy. Celem badań miało być więc zrekonstruowanie źródeł potęgi kultury wizualnej, zdemaskowanie obrazów jako środków sprawowania kontroli, ujawnienie drzemiących w niej antyliberalnych i antydemokratycznych potencji. W efekcie kultura wizualna jako przedmiot analiz stała się też ulubionym środkiem artykułowania krytyki systemu, modernizacji, nowoczesności i hegemonii klas dominujących. Obrazy stawały się bardzo wygodnym przedmiotem ataku, bo nie tylko niemym i bezbronnym, ale też otwartym na wypełnienie go dowolnymi znaczeniami. Również w tym wypadku obrazy wystąpiły, jak powiedziałby W. J. T. Mitchell, w roli „podwładnego” 13 , który nie tylko pozwala urzeczywistniać nasze cele, ale również niezbędny jest po to, by ustanowić naszą własną

7 A. Gell, Art and Agency: An Anthropological Theory, Oxford University Press, Oxford 1998.

8 D. Freedberg, Potega wizerunków. Studia z historii i teorii oddziaływania, tłum. E. Klekot, Wydawnictwo UJ, Kraków 2005.

9 H. Belting, Antropologia obrazu. Szkice do nauki o obrazie, tłum. M. Bryl, Universitas, Kraków 2007.

10 D. M. Levi (red.), Modernity and Hegemony of Vision, University of California Press, London-Berkeley 1993; T. Mitchell, Egipt na wystawie świata, tłum. E. Klekot, PIW, Warszawa 2001; M. Jay, Nowoczesne władze wzroku, tłum. M. Kwiek, w: E. Rewers (red.), Przestrzeń, filozofia, architektura, Wydawnictwo Fundacji Humaniora, Poznań 1999.

11 E. Goffman, Piętno. Rozważania o zranionej tożsamości, tłum. A. Dzierżyńska, J. Tokarska-Bakir, Gdańskie Wydawnictwo Psychologiczne, Gdańsk 2005.

12 J. Baudrillard, Społeczeństwo konsumpcyjne, tłum. S. Królak, Sic!, Warszawa 2006; M. Gołębiewska, Demontaż atrakcji. O estetyce audiowizualności, słowo/obraz terytoria, Gdańsk 2003.

13 W. J. T. Mitchell, What Do Picture Want? The Lives and Loves of Images, University of Chicago Press, Chicago 2005. 
dominację. Mówiąc jeszcze inaczej, badania nad kulturą wizualną miały ją zracjonalizować przede wszystkim jako środek panowania, a tym samym osłabiać potęgę obrazów przez wskazanie, iż są one zrozumiałe, ponieważ są tylko narzędziem w rękach człowieka. Paradoks obrazu jako „podwładnego” polega jednak na tym, że umożliwiając ustanowienie relacji władzy (wobec niego i poprzez niego wobec rzeczywistości), zaczyna on władzę sprawować, również nad tymi, którzy próbują demaskować jego rolę w procesach panowania.

Dlatego też dużo bardziej od pojęcia „kultura wizualna” cenię inne, a mianowicie „wizualność”. Przede wszystkim dlatego, że obejmuje ono swoim zakresem nie tylko to, co podpada pod ten pierwszy termin, ale również te aspekty naszego doświadczenia wzrokowego, które nie są społecznie uregulowane, które wymykają się temu, co symboliczne, znaczeniowe, intersubiektywne, te, które z porządku wykluczono, by mógł być on porządkiem, ale które są jednocześnie dostępne jednostkom. Kategoria ta obejmuje więc zarówno to, co widzą wszyscy, jak i to, co są w stanie dostrzec pojedyncze jednostki, zarówno to, co jest elementem społecznej wyobraźni, jak i to, co kształtuje wyobraźnię indywiduów, zarówno to, co da się wyrazić poprzez dostępne w danej kulturze reprezentacje, jak i to, co nie poddaje się tego typu translacji itd.

„Wizualność” jako pojęcie w stopniu dużo wyższym niż „kultura wizualna” zdaje więc sprawę ze złożoności doświadczenia ludzkiego, którego źródłem jest wzrok. W tej perspektywie obrazy to nie tylko „podwładni” służący człowiekowi, ale też partnerzy interakcji, „spojrzenia” pozwalające nam doświadczyć pragnień, które wyparliśmy, aby stać się określonym typem osoby, obiekty wywołujące wzruszenie, strach, doznania estetyczne, przedmioty, których nie da się odczytać, ale które zmuszają, by coś z nimi zrobić (zniszczyć, zasłonić, powielić, przesłać znajomym) itd. „Wizualność” jako pojęcie nie redukuje więc tego, co jest widzialne (a więc potencjalnie do zobaczenia), wyłącznie do pełniania funkcji regulacyjnych i pozwala dostrzec, iż nie wszystko, co jest widzialne, jest społecznie i kulturowo wyreżyserowane. Siły obrazów stających przez naszymi oczami, bądź przywoływanych przez naszą wyobraźnię, nie da się zredukować do mocy narzucania nam przekonania, iż sposób, w jaki widzimy świat, jest tożsamy z tym, w jaki sposób doświadczają go inni, bo siła ta polega też na dawaniu nam sposobności odkrywania, iż jest to domniemanie nie poparte wystarczającymi dowodami. Obrazy więc równie silnie uwspólniają nasze doświadczenia, co pozwalają doświadczyć każdej jednostce jej odrębności i wyjątkowości. Dzięki nim stajemy się zarówno członkami społeczeństwa, jak i odkrywamy, czym został okupiony ten proces. Obrazy pozwalają nam refleksyjnie budować naszą tożsamość, ale też nie pozwalają zapomnieć o tym, co zostało wyparte, byśmy mogli być w pełni tym, za kogo aktualnie się uważamy. Potęga obrazów drzemie więc nie tylko $\mathrm{w}$ wielowymiarowej ambiwalencji odpowiedzialnej za poznawcze problemy, których nam one dostarczaja, ale przede wszystkim w dwuznaczności roli, którą odgrywają w życiu społecznym i indywidualnym, w życiu wspólnot i jednostek. 
Czy, jak i po co badać kulturę wizualną? Dzięki bardzo wielu studiom poświęconym analizom kultury wizualnej stosunkowo dobrze poznaliśmy jej funkcje $\mathrm{w}$ nowoczesnych społeczeństwach, w praktykach towarzyszących ich ustanawianiu oraz reprodukcji: wiemy, jak konstruowane są obrazy propagandowe i reklamowe ${ }^{14}$, oczywisty jest dla nas mechanizm przemocy symbolicznej ${ }^{15}$, ikonicznej ${ }^{16}$, mitu $^{17}$, imagologii ${ }^{18}$, symulacji ${ }^{19}$, ekranu $^{20}$. Wiemy, na czym polega panoptyczne panowanie ${ }^{21}$, władza aparatu ${ }^{22}$ i „spojrzenia” 23 . W pełni odtworzono też rolę wizualnych reprezentacji w procesach uobecniania i unieobecniania rzeczywistości ${ }^{24}$. Wszystkie te ustalenia, niezależnie od ich różnorodności, są odpowiedziami na zaledwie jedno pytanie. Pytanie o to, w jaki sposób obrazy służą człowiekowi w procesach konstruowania porządku społecznego. Z konieczności więc poszukiwanie odpowiedzi na nie jest skoncentrowane na tych typach wizualności, które mają charakter dominujący (najbardziej rozpowszechniony i związany z tymi, którzy dominują), a więc tych, których użyto, by porządek stwarzać.

Pytanie o to, co powinniśmy badać zajmując się kulturą wizualną, jest $\mathrm{w}$ istocie problemem tego, czego jeszcze o niej nie wiemy. Nie wiemy zaś przede wszystkim tego, co zasłania interesujące nas tu pojęcie, a więc na przy-

14 P. Messaris, Visual Persuasion: The Role of Images in Advertising, Sage, London-Thousand Oaks 1997; A. Pitrus, Znaki na sprzedaż. W stronę integracyjnej teorii reklamy, Rabid, Kraków 2000; R. Heath, Ukryta moc reklamy. Co tak naprawdę wptywa na wybór marki, tłum. A. Nowak, Gdańskie Wydawnictwo Psychologiczne, Gdańsk 2006; E. Szczęsna, Poetyka reklamy, Wydawnictwo Naukowe PWN, Warszawa 2005; T. Clark, Art and Propaganda in the Twentieth Century: The Political Images in the Age of Mass Culture, Calmann \& King, New York 1997; Iconography, Propaganda, and Legitimation, A. Ellenius (red.), Clarendon Press of Oxford University, New York 1998; Teoria i praktyka propagandy, B. Dobek-Ostrowska (red.), Wydawnictwo Uniwersytetu Wrocławskiego, Wrocław 1999; O. Thompson, Historia propagandy, tłum. S. Głąbiński, Książka i Wiedza, Warszawa 2001.

15 P. Bourdieu, Dystynkcja, tłum. P. Biłos, Scholar, Warszawa 2006.

16 R. Drozdowski, Obraza na obrazy, Wydawnictwo Naukowe UAM, Poznań 2007; E. Wilk (red.), Przemoc ikoniczna czy nowa widzialność, Wydawnictwo Uniwersytetu Śląskiego, Katowice 2001; A. Ogonowska, Przemoc ikoniczna, Wydawnictwo Naukowe Uniwersytetu Pedagogicznego, Kraków 2004.

17 R. Barthes, Mitologie, tłum. A. Dziadek, KR, Warszawa 2000; R. Barthes, Retoryka obrazu, tłum. Z. Kruszyński, w: M. Skwara, S. Wysłuch (red.), Ut pictura poesis, słowo/obraz terytoria, Gdańsk 2006, s. 139-158.

18 M. C. Taylor, E. Saarinen, Imagologies. Media Philosophy, Routledge, London 1994.

19 J. Baudrillard, Wojny w zatoce nie byto, tłum. S. Królak, Sic!, Warszawa 2006; G. Debord, Społeczeństwo spektaklu, tłum. A. Ptaszkowska, słowo/obraz terytoria, Gdańsk 1998.

20 A. Gwóźdź, P. Zwojski (red.), Wiek ekranów, Rabid, Kraków 2002.

${ }^{21}$ M. Foucault, Nadzorować $i$ karać, tłum. T. Komendant, Fundacja Aletheia, Warszawa 1998.

22 V. Flusser, Ku filozofii fotografi, tłum. J. Maniecki, Wydawnictwo Akademii Sztuk Pięknych, Katowice 2004.

23 T. McGowan, Realne spojrzenie. Teoria filmu po Lacanie, tłum. K. Mikurda, Krytyka Polityczna, Warszawa 2008.

24 S. Hall (red.), Representation: Cultural Representation and Signifying Practices, Sage, London 1997; M. P. Markowski, Pragnienie obecności. Filozofie reprezentacji od Platona do Kartezjusza, słowo/obraz terytoria, Gdańsk 1999. 
kład, czym są dla jednostek obrazy oraz dlaczego nasze reakcje na nie bardzo często nie mieszczą się w tym, co jest możliwe do zobaczenia. Nie wiemy więc, dlaczego nastolatki noszą T-shirty $z$ wizerunkami seryjnych morderców i rewolucjonistów, których dokonań nie znają, ani dlaczego kierowcy ciężarówek ozdabiają kabiny swoich pojazdów jednocześnie religijnymi symbolami i fotografiami rozebranych dziewczyn. Trudno nam też odpowiedzieć na pytanie, dlaczego wieszamy $\mathrm{w}$ domach dzieła sztuki bądź ich reprodukcje, choć większość z nas nie cierpi sztuki i jej nie rozumie. Nie do końca jasne jest też nasze bezgraniczne zaufanie do fotografii przy całej świadomości tego, jak bardzo zmanipulowanym rodzajem świadectwa jest ona. Tajemnicę stanowi zarówno to, dlaczego przemysł reklamowy kwitnie, mimo że nikt nie wierzy reklamowym obrazom, jak i to, dlaczego niżej lub wyżej rangujemy wiarygodność telewizyjnych programów informacyjnych, choć wiemy, że telewizja z definicji nie jest w stanie mówić prawdy o rzeczywistości. Niezrozumiałe jest też to, dlaczego niektórych z nas podniecają obrazy, choć wiemy, iż ich stworzenie wymagało uprzedmiotowienia i zastosowania przemocy. Trudno nam też odpowiedzieć na pytanie o to, dlaczego warto tworzyć obrazy, choć ceną za ich kreację jest nieludzki trud, cierpienie, a czasem, jak w przypadku zdjęć wykonywanych przez reporterów wojennych, również poświęcenie życia. Niejasne są też dla nas powody, dla których niektóre obrazy są ogromnie witalne, inne zaś po jednej, krótkotrwałej ekspozycji znikają na zawsze. Nie wiemy, dlaczego ludzie klękają przed obrazami, skoro doskonale widzą, że to tylko malowidła, płótna pokryte barwnymi plamami, ani dlaczego oddają ostatnie pieniądze, potrzebne do przetrwania, by wejść $\mathrm{w}$ posiadanie stworzonych przez artystę wizerunków.

Pytania te można mnożyć, łączy je zaś to, że nie jesteśmy w stanie na nie odpowiedzieć posługując się kategorią „kultura wizualna” i opierając się na przekonaniu, iż główną funkcją obrazów jest regulowanie sposobów doświadczania rzeczywistości przez członków określonej społeczności. Dlatego też nie powinniśmy badać „kultury wizualnej”, ale raczej „wizualność” (rozumianą w wyżej wskazany sposób), a także zamiast koncentrować się na wąsko rozumianych potencjach regulacyjnych tego, co naoczne, powinniśmy raczej skupić się na relacjach łączących ludzi i obrazy, uczynić przedmiotem naszego zainteresowania interakcje zachodzące między nami a nimi. Tylko w ten sposób, a więc traktując obrazy nie jako podwładnych, ale jako partnerów, jesteśmy w stanie dostrzec tożsamość tego, co społeczne, ale też ludzkie i indywidualne, z tym, co wizualne.

Mówiąc jeszcze inaczej, chodzi nie tylko o to, by pytać, co ludzie robią z obrazami, ale też o to, co obrazy robią z ludźmi, nie tylko o to, po co je tworzymy, ale też o to, w jaki sposób one nas stwarzają. Takie zdefiniowanie problemu analiz wizualności oznacza, iż ich przedmiot to przede wszystkim pytanie, jak obrazy dane są jednostkom $\mathrm{w}$ ich codziennym doświadczeniu, nie zaś tylko i wyłącznie w wybranych enklawach (takich jak odbiór telewizji, oglądanie dzieł sztuki w muzeum lub galerii, wykonywanie zdjęć podczas wakacji itd.). 
Oznacza ono również, iż badanie wizualności powinno być poświęcone rekonstrukcji tego, co my wszyscy, a nie tylko imagolodzy (krytycy i historycy sztuki, artyści i pracownicy mediów, estetycy czy socjologowie i antropolodzy wizualni itd.), robimy z obrazami. Przedmiotem tak rozumianych badań nie powinno być również tylko i wyłącznie patrzenie na obrazy, ale także wszystko to, co prowadzi do ich powstania i co sprawia, iż pojawiają się one oraz znikają, a więc złożone systemy wiedzy, technologie, praktyki ekonomiczne i polityczne, nasze przyzwyczajenia związane $z$ ich eksponowaniem, porządkowaniem, przechowywaniem i usuwaniem. W centrum badań wizualności powinno znajdować się więc przede wszystkim pytanie o życie obrazów, pytanie o ich zdolność do ustanawiania i kształtowania relacji konstytuujących życie społeczne i decydujących o tym, kim są jednostki.

Posługiwanie się terminem „wizualność”, zamiast „kultura wizualna”, nie tylko pozwala dostrzec, iż to, co zbiorowe, nie jest możliwe bez tego, co naoczne i wyobrażone, ale też, że nie wszystkie aspekty naszego życia są kulturowo uregulowane. Najbardziej fascynujących polem analiz wizualności są więc te jej aspekty, które ustanawiają relacje konstytuujące społeczeństwo, ale które jednocześnie nie są częścią ładu, lecz poza niego wyrastają, nie mieszą się w jego obrębie, nie dają się $\mathrm{w}$ jego obrębie pomyśleć. Badania wizualności powinny więc $\mathrm{w}$ moim przekonaniu dotyczyć przede wszystkim tych relacji z obrazami, których najlepszą ilustracją jest mit Pigmaliona. Mit przywołujący pragnienia ludzi odrzucających porządek i powołujących do życia obrazy, które porządek zmieniają. Mit pokazujący możliwość istnienia obrazów, które nie mieszczą się w tym, co możliwe do zobaczenia, ale które jednocześnie zmieniają pole widzialności.

\section{JERZY LEWCZYŃSKI}

Fotografik

Co to jest kultura wizualna?

To obecność w życiu społecznym sztuki w postaci obrazu i pochodnych.

To wpływ sztuki na stan świadomości społecznej Narodu.

Kultura wizualna to codzienny „pacierz i rachunek sumienia” zarówno z dokonanych, jak i poznanych wartości artystycznych.

Kultura wizualna to budowa nowego społeczeństwa XXI wieku, to przebudowa świadomości wypierającej dawne uprzedzenia i antagonizmy.

Kultura wizualna to szkoła patrzenia na rzeczywistość i wpływ na procesy wychowawcze wstępujących pokoleń.

Kultura wizualna to archiwum przemian i zachowań w tle historycznym.

Kultura wizualna to możliwość poznania wielu zjawisk naukowych i społecznych. 
Kultura wizualna to możliwość opisania sytuacji człowieka w obszarze zjawisk i jego zależność od programów prognozujących los jednostki ludzkiej.

Czy, jak i po co badać kulturę wizualną?

Stworzyć możliwość archiwizacji określonych zachowań w obszarze kultury i sytuacji, jak: festiwale, konkursy, publikacje, a także destrukcyjne działania widowisk sportowych.

Rozważyć możliwość oceny społecznej skutków prowadzonych badań naukowych i artystycznych oraz ich wpływu na etyczną postawę odbiorcy.

Ocenić przydatność ocen i zachowań w publikacjach dotyczących sztuki i kultury.

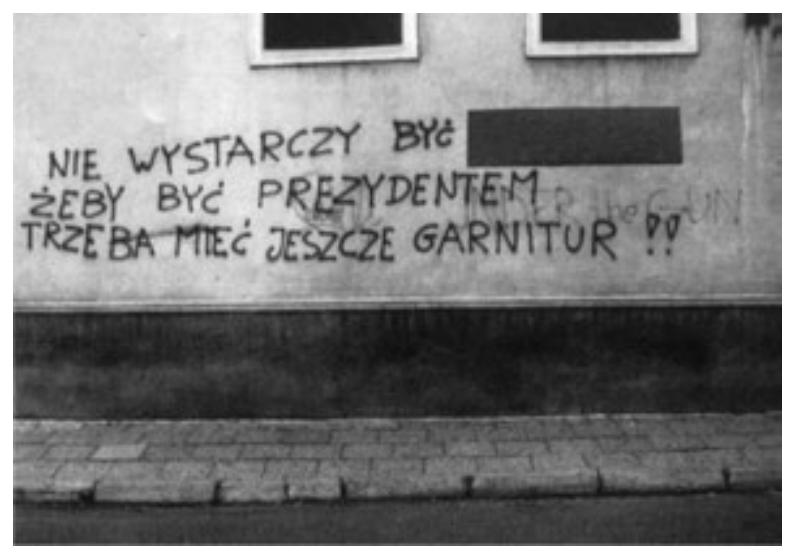

Do odpowiedzi Jerzy Lewczyński dołączył zdjęcie. Widoczny na nim szary pasek został przez niego doklejony tak, że po odchyleniu widać ukryte pod nim słowo „ch..." (przyp. red.).

\section{SŁAWOMIR MAGALA*}

Department of Organization and Personnel Management

Rotterdam School of Management

Jeden z ostatnich esejów Susan Sontag poświęcony był fascynacji środków masowego przekazu okrucieństwami wojen. W Regarding the Pain of Others Sontag opisuje scenę z oblężonego Sarajewa. Kryjący się przed ostrzałem artylerii tubylcy dostrzegają fotoreportera. - I co, czekasz aż wybuchnie, żeby zrobić zdjęcia trupom? - oburzają się, zdając sobie sprawę, że mają posłużyć jako mięso armatnie w globalnym społeczeństwie spektaklu, zgodnie z zasadą: „Jeśli krew zostanie przelana - pierwsza strona gwarantowana". W jakiej kulturze wizualnej wolno seks i śmierć uznawać za dopuszczalne „przyprawy” podwyż-

\footnotetext{
*Autor nadał swojej wypowiedzi tytuł „Znaczenia zapatrzenia” (przyp. red.).
} 
szające konkurencyjność „strawy dla oczu”, podawanej przez prawie cały czas, prawie wszędzie, prawie wszystkim?

Kulturę wizualną (w jej podstawowym znaczeniu jako całokształt praktyk komunikacyjnych $z$ rosnącą przewagą oka nad uchem) rozumiem jako historyczny kompromis, porównywalny z Unią Europejską albo internetem, z Igrzyskami Olimpijskimi albo powolnym, ale realnym równouprawnieniem kobiet. Po pierwsze zatem - kultura wizualna to taka kultura, w której brak niewzruszonych autorytetów z powodzeniem broniących rdzennych wartości (przeświecających spoza obrazów, którymi rozmawiamy) przed zmianą i renegocjacją powoduje, iż ząb czasu narusza sens życia i rozmowy, czyli zmienia znaczenia nadawane naszym oraz cudzym czynom i marzeniom, których nieustanna krytyka i renegocjacja możliwe są dzięki telekomunikacyjnie wszechobecnym multimediom. Żyjemy w społeczeństwie spektaklu, ale zarazem jako widzowie i aktorzy, krytycy i producenci, wychowawcy i konsumenci.

Po drugie, kulturę wizualną, rozumianą jako zdefiniowany i instytucjonalnie usystematyzowany obszar krytycznej i teoretycznej refleksji oraz akademickiego nauczania, widzę jako interdyscyplinarny skutek tymczasowego ponadparadygmatycznego sojuszu przedstawicieli różnych rodzajów sztuki, takich akademickich dyscyplin jak antropologia, socjologia, filozofia, estetyka filmu, fotografii, multimediów, teoria i historia sztuki. Pojawiają się próby radykalizacji - cytuje się pytanie Godarda o to, dla kogo i przeciwko komu wynaleziono fotografię (Allan Sekula), albo wykorzystuje się Waltera Benjamina czy Michela Foucaulta do stworzenia ekonomicznie i politycznie krytycznej „archeologii" wizualnej (Douglas Crimp), czyli do wymyślenia interdyscyplinarnych programów metodologicznych zdolnych przynieść odpowiedzi na pytania, na których stawianiu elitom i establishmentom ani w polityce, ani w humanistyce nie zależy (Manuel Castells, W.J.T. Mitchell, Jonathan Crary, Margaret Dikovitskaya). W Polsce „antropologią obrazu” zajmują się socjologowie, między innymi Krzysztof Olechnicki i Piotr Sztompka.

Po trzecie, kulturę wizualną widzę jako nowy wielki projekt samokształceniowy naszych społeczeństw - po religijnym (od walki z grzechem do zbawienia) i oświeceniowym (od walki z wyzyskiem do równouprawnienia) - projekt ten ma nas wyzwolić z piramidalnych hierarchii i powieść ku egalitarnej komunikacji i usieciowionej emancypacji (Google i Wikipedia silniej mówią do mnie niż akredytacji lub habilitacji szkiełko i oko). Widzę sens badania kultury wizualnej z punktu widzenia możliwej zmiany procesów gromadzenia i szybkiego wykorzystywania wiedzy. Kultura wizualna już doprowadziła do przesunięcia się punktu ciężkości komunikacji społecznej od encyklopedyzacji do wikipedyzacji i od kina do teledysku jako rytuału nawigacyjnego w wirtualnych przestrzeniach multimedialnej telekomunikacji. Nie jest to perspektywa wesoła dla akademicko wykształconej inteligencji - bo na cóż wieloletnie terminowanie $\mathrm{w}$ archaicznych strukturach instytucjonalnych, skoro w Wikipedii uchowa się czasem wiedza sparodiowana w znanym wierszyku „Kiedy Kara 
Mustafa, wielki mistrz Krzyżaków, na czele kosynierów uderzał na Kraków". To prawda, ale właśnie dzięki nadmiernie wykształconym i uprzywilejowanym $\mathrm{w}$ dostępie do internetu fachowcom deletopedia też nie śpi i Wikipedia potrafi się oczyszczać. Chodzi o zachowanie i wykorzystanie szans, by dziad przemawiał do obrazu, gdyż wbrew znanemu przysłowiu, to raczej obrazy się rozgadały, a dziady milczą. Podam dwa przykłady. Kiedy amerykański fotograf, Spencer Platt, wykonał zdjęcie młodym Libańczykom przejeżdżającym w kabriolecie między dymiącymi gruzami kamienic zburzonych przez izraelskie samoloty $\mathrm{w}$ Bejrucie, gazety całego świata opublikowały je z kąśliwym komentarzem na temat „turystyki śmierci”, sugerując, że młodzi yuppies bawią się cudzym nieszczęściem. Bohaterzy zdjęcia zaprotestowali, że od lat pracują dla organizacji dobroczynnych i właśnie sporządzali spis najbardziej palących potrzeb ofiar - i te same gazety sprostowania ich zamieściły, podobnie jak strony internetowe gazet i stacji telewizyjnych. Przykład drugi. Kiedy Milczo Manczewski debiutował swoim filmem o konfliktach między chrześcijanami a muzułmanami w Macedonii (Przed deszczem, 1994), nie tylko wydrwił ideologię religijno-etnicznej czystości w służbie politycznych ambicji, ale i pokazał, że Bałkany to nie egzotyczny barbarzyńca w europejskim ogrodzie, że nie da się o ich mieszkańcach mówić schematami „nasyconej seksem rozrywki albo wysublimowanej, sentymentalnej brutalności" ${ }^{1}$. Londyn i Sarajewo są równie europejskie i żadne $z$ nich nie może być tylko kopalnią malowniczych i podszytych wojennymi zbrodniami fotografii. Żaden zakątek świata nie może być kolonią, z której rabuje się wizualne surowce dla zaspokojenia wybrednego konsumenta w gospodarce, w której uwagę przykuć jest trudniej niż pożyczyć kapitał, zmobilizować robotników albo wykorzystać wiedzę. Dzięki postępom kultury wizualnej widać to dzisiaj lepiej niż wczoraj — chciałoby się powiedzieć „gołym okiem”, ale gołe to ono na pewno nie jest.

4 lipca 2009 r. Krimpen a/d IJssel, Holandia

\author{
MARIANNA MICHAŁOWSKA* \\ Zaktad Kultury Miasta \\ Instytut Kulturoznawstwa \\ Uniwersytet im. Adama Mickiewicza w Poznaniu
}

Swoją wypowiedź na temat kultury wizualnej przedstawioną w Visual Culture Questionnaire w 1996 r. Susan Buck-Morss rozpoczyna od opinii: „produkcja dyskursu kultury wizualnej wymaga likwidacji takiej sztuki, jaką znali-

\footnotetext{
1 Cyt. za: K. Marciniak, Alienhood?: Citizenship, Exile, and the Logic of Difference, University of Minnesota Press, London-Minneapolis 2006, s. 130.

*Autorka zatytułowała swoją wypowiedź „Kultura wizualna i jej sensorium” (przyp. red.).
} 
śmy dotychczas" ${ }^{1}$. Przyczyn takiej sytuacji upatruje Buck-Morss w społecznym umiejscowieniu sztuki, której nie sposób analizować jako oddzielonej od praktyk społecznych oraz bez dostrzeżenia dominującej roli instytucji kulturowych. Rolą twórcy miałoby być między innymi przeciwstawianie się instytucjom muzealnym, „podtrzymującym iluzję, że sztuka nadal istnieje” ${ }^{2}$. Wprowadzenie pojęcia kultury wizualnej miało wspomóc ten krytyczny opór. Jednocześnie powołane w ramach dyskursu akademickiego „studia wizualne” reprezentowały analityczny potencjał krytyków kultury. Jak zauważa Buck-Morss, wraz $z$ ekspansją visual studies także ich obszar należałoby poddać krytyce. Chociaż visual studies nie potrafiły wytworzyć spójnego programu, produkując rozliczne „teoretyczne bańki” (dostało się tu psychoanalizie), to jednak wypracowały również zestaw standardowych tematów opartych na lekturach Barthesa, Benjamina, Foucaulta i Lacana. Najważniejsze z nich, to: „reprodukcja obrazów, społeczeństwo spektaklu, wizualna wyobraźnia Innego, reżimy wzroku, symulacje, fetysz, (męskie) spojrzenie czy maszyna oka" ${ }^{3}$. Czy do analizy tych tematów, pyta Buck-Morss, potrzebna jest kultura wizualna? W opinii autorki bardziej potrzebna dzisiaj jest krytyczna analiza społecznego funkcjonowania obrazu niż legitymowanie ich „kulturowości” 4 .

Opinia Buck-Morss znakomicie reprezentuje dylematy badaczy tworzących szkielet studiów wizualnych ${ }^{5}$. Ta nowa u schyłku zeszłego wieku dziedzina, pod przewodnictwem Normana Brysona, Svetlany Alpers, Sylvii Kolbowski czy Jonathana Crary'ego, obrazowała opozycje istniejące w łonie historii sztuki i literaturoznawstwa, a jednocześnie nakreślała pole dla badań interdyscyplinarnych. We wprowadzeniu do tomu poświęconego kulturze wizualnej redaktorzy przywołują słowa Jonathana Cullera, który zauważał, że konsekwencją użycia tego terminu było odejście od teorii rozumianej jako opis metod interpretacji na rzecz „dyskursu, którego konsekwencjami są koncepcje natury i znaczenia

\footnotetext{
1 S. Buck-Morss, Visual Culture Questionnaire, „October” 1996, t. 77, s. 29.

2 Tamże.

3 Tamże.

4 Tamże, s. 30.
}

5 Podobną diagnozę można odnaleźć w polskiej refleksji o stanie współczesnej sztuki. Warto przypomnieć w tym kontekście dyskusję Grzegorza Dziamskiego z Grzegorzem Sztabińskim. Autorzy polemiki zwracali uwagę na zmiany dokonujące się w obszarze sztuki wraz z pojawianiem się dyskursu kulturowego (teorii postkolonialnych czy genderowych) w zglobalizowanym świecie. Pierwszy zauważał, iż w dyskursie multi- i transkulturowym kultura wizualna wydaje się bardziej poprawna niż sztuka, ponosząca konsekwencje europocentrycznej wizji świata. Również wobec badań produktów popularnej wyobraźni kultura wizualna wydaje się bardziej "gościnna” dla różnorodnych przejawów ludzkiej twórczości, $z$ kolei dla drugiego $z$ dyskutantów istotne było zachowanie pojęcia sztuki, lecz w przewrotnym, negatywnym odniesieniu. Zob. G. Sztabiński, Czy pojęcie „sztuka” jest nam jeszcze potrzebne? oraz G. Dziamski, Od sztuki do kultury wizualnej, w: T. Kostyrko, G. Dziamski, J. Zydorowicz (red.), Sztuka wspótczesna $i$ jej filozoficzne komentarze, Instytut Kulturoznawstwa UAM, Poznań 2004. 
tekstów oraz ich relacje do innych dyskursów, społecznych praktyk i ludzkich podmiotów" 6 .

Jakie zatem problemy wydawały się najważniejsze dla autorów „Kwestionariusza" ponad dziesięć lat temu? Można by, jak sądzę, wyróżnić co najmniej dwa $z$ nich: na pierwszym planie stawiano konflikt studiów wizualnych i historii sztuki, sprowokowany ekspansją nauk społecznych, a następnie pytanie o relację autonomii poszczególnych dziedzin badań nad kulturą do postulowanej przez zwolenników kultury wizualnej interdyscyplinarności.

Patrząc z dzisiejszej perspektywy trudno nie dostrzec, że pytania wówczas stawiane nie doczekały się jasnej odpowiedzi, a pojęcie kultury wizualnej, wraz z coraz liczniejszymi tomami na jej temat, traciło swoją wyrazistość (której, być może, nigdy nie miało).

Dlatego, jak sądzę, warto tu przypomnieć inną — poza „Kwestionariuszem” - istotną próbę wzmocnienia teoretycznych fundamentów kultury wizualnej. W 2003 r. Mieke Bal artykułem Visual Essentialism and the Object of Visual Culture, opublikowanym w „Journal of Visual Culture”, sprowokowała kolejną dyskusję wokół omawianego terminu. Ponownie pretekst dla artykułu stanowiła tradycja historii sztuki, lecz konsekwencje jej ujęcia biegły w nowym kierunku, ponieważ nie postulowano tu przekształcenia tego, co jest, lecz powołanie nowej dyscypliny.

„Czy «kultura wizualna» jest dyscypliną? — pyta Bal. I odpowiada — Pierwszą, oczywistą odpowiedzią jest «nie», ponieważ jej obiekt nie może być studiowany zgodnie $z$ jakimkolwiek obecnym paradygmatem dyscypliny. $Z$ pewnością nie jest dziedziną historii sztuki. $Z$ drugiej strony, wysuwa się na pierwszy plan, ponieważ ta dyscyplina [historia sztuki] poniosła klęskę zarówno zajmując się wizualnością obiektów - ze względu na dogmatyczną pozycję "historii" - jak i stanowiąc kolekcję tych obiektów - ze względu na ustalone znaczenie «sztuki». Traktować kulturę wizualną jako historię sztuki w perspektywie studiów kulturowych to skazywać się na powtarzanie tego samego błędu" 7 .

Autorka podkreśla, że dla analizy obiektów wizualnych dzisiaj należy szukać innych metod niż ograniczające pole interpretacji podejścia historii sztuki. $\mathrm{W}$ ten sposób dochodzi do przekonania, że wizualność wymaga interdyscyplinarności, która zresztą jest już zakorzeniona w samej kulturze wizualnej. „Jakakolwiek próba wyartykułowania celów i metod studiów nad kulturą wizualną musi poddać analizie terminy w ich znaczeniu negatywnym: "wizualny» jako «nieczysty» — synestetyczny, dyskursywny i pragmatyczny; «kultura» zaś

${ }^{6}$ N. Bryson, M. A. Holly, I K. Moxey (red.), Visual Culture: Images and Interpretations, Wesleyan University Press, Middletown 1994, s. xv.

7 M. Bal, Visual Essentialism and the Object of Visual Culture, „Journal of Visual Culture” 2003, t. 2(1), s. 5 . 
jako zmienna, zróżnicowana, umieszczona pomiędzy «strefami kultury» oraz realizowana poprzez praktyki władzy i oporu" ${ }^{8}$.

Koncepcja interdyscyplinarności idzie tu $\mathrm{w}$ parze $\mathrm{z}$ przedstawioną $\mathrm{w}$ książkach Bal metodą analizy kulturowej, w której analizując (czy też, jak pisze Bal, „teoretyzując”) obiekt, spogląda się poprzez focus, ognisko czy soczewkę wpływającą na jego narrację. Dzięki temu, by użyć fotograficznej metafory, nabiera on „głębi ostrości”. Studia wizualne zatem mają nie dawać jednoznaczną odpowiedź na pytanie o sens dzieła, lecz wprowadzać je w dyskurs kulturowych znaczeń.

W odpowiedzi na artykuł Bal W. J. T. Mitchell (powiedziałabym, że podobnie jak Buck-Morss wcześniej) zaproponował wprowadzenie rozróżnienia między terminami visual culture a visual studies, określając pierwszą jako obszar prowadzenia badań, drugie zaś jako przedmiot. „Kultura wizualna — pisał - jest wizualną konstrukcją społecznego, a nie tylko społeczną konstrukcją widzenia" ${ }^{9}$. Stwierdzenie Mitchella wyznacza perspektywę badawczą, zgodnie z którą uznaje się, że w ramach studiów wizualnych badamy to, jak reprodukowany jest społeczny wizerunek. Ujęcie autora City of Bits stanowiłoby zatem głęboko przemyślane przetworzenie diagnozy Michela Foucaulta. Mówiąc prościej: kultura wizualna jest konstrukcją społeczną, studia wizualne zaś odkrywaniem systemu, który za ową konstrukcja stoi. Znowu podkreśla się krytyczny w stosunku do obszaru kultury wizualnej charakter studiów wizualnych, ponieważ ich celem nie jest właściwie analiza obrazu, lecz mechanizmów, które sprawiły, że w taki a nie inny sposób nam się on ukazuje.

Do koncepcji konstrukcjonistycznych odwoływała się także Bal, pisząc: „być może najbardziej istotnym zadaniem kultury wizualnej [...] jest rozumienie niektórych motywacji wizualnego esencjalizmu, który promuje spojrzenie wiedzącego (Foucault), zachowując je niewidzialnym" ${ }^{10}$. Zadaniem studiów jest krytyczna analiza, która odsłoni pretensje obrazu do bycia naturalnym, transparentnym. Obraz wcale nie pokazuje nam tego, co jest - wręcz przeciwnie - jego uprzywilejowana, ujawniona narracja przysłania inne. Dopiero podejście krytyczne, usytuowanie obrazu w kontekście kultury wizualnej obnaży ten dominujący kontekst ${ }^{11}$.

Określanie sensorium: dyskurs zmysłów. Zwróćmy uwagę na jeszcze jeden kontekst kultury wizualnej - jej paradoksalne dążenie do przekroczenia granicy wizualności. Nikogo bowiem chyba nie trzeba już dzisiaj przekonywać, iż to, co nazywamy kulturą wizualną, nie obejmuje wyłącznie wizualności, lecz także audialność (warto wspomnieć o funkcjonującym od dawna w polskiej

8 Tamże, s. 19

9 W. J. T. Mitchell, Showing Seeing: A Critique of Visual Culture, „Journal of Visual Culture” 2002, t. 1(2), s. 170.

10 M. Bal, Visual Essentialism..., cyt. wyd., s. 22.

11 Tamże. 
teorii sztuki pojęciu kultury audiowizualnej ${ }^{12}$ ), przestrzenność i taktylność. W obszarze tej wielosensoryczności sztuki „kultura wizualna” to tylko uproszczenie terminologiczne, a także wskazanie na (wciąż obecne mimo trwającej od wielu lat krytyki wzrokocentryzmu) uprzywilejowanie spojrzenia wobec pozostałych czterech zmysłów.

O tym, że nie jest to problem nowy, świadczą słowa Susan Sontag z 1966 r. Autorka Przeciw interpretacji pisała wówczas: „musimy nauczyć się widzieć więcej, słyszeć więcej i czuć więcej" 13 , i chociaż stawiała wtedy odpór hermeneutyce, to dzisiaj moglibyśmy jej słowa wpisać w nurt oporu nadmiarowi widzenia, które sprawia, że - przekornie mówiąc - przestajemy patrzeć. O potrzebie przekraczania wzroku świadczą współczesne koncepcje sensoryczności, związanej przede wszystkim $z$ nowymi mediami ${ }^{14}$.

Jednak funkcjonowanie obrazów w ramach kultury wizualnej, co ciekawe, dotyczy także tego ucieleśnionego medialnie doświadczenia. Pozostańmy w tym miejscu w kręgu rozważań Mieke Bal i przywołajmy jej analizę realizacji współczesnej fińskiej artystki wizualnej Eiji-Liisy Ahtili. Ahtila tworzy wieloekranowe projekcje audiowizualne. Krytyczka wprowadza w tekście pojęcie „języka afektu”. Pisze: „patrzenie utrudnia bycie. Słuch i wzrok nie mogą już pojawiać się jednocześnie, a bycie musi podporządkować się jednemu z dwojga" 15 . Bohaterki realizacji Ahtili na skutek psychozy tracą zdolność rozpoznania zmysłów dostarczających im wiedzy o otoczeniu. Wspólne, multisensoryczne doświadczenie zaś jest konieczne, by dotrzeć do znaczenia dzieła. Staje się ono możliwe dzięki afektowi - psychicznemu wrażeniu, które uzupełnia to, co zmysłowe ${ }^{16}$.

Taki afektywny projekt analizy dzieła wyznacza relację krytyki, dzieła i odbiorcy. „Krytyka jest aktem mediacji” 17 — pisze autorka. Mediacji między dziełem a widzem, w celu nie tyle wyjaśniania tego pierwszego, ile jego „otwarcia na przekłady innego rodzaju, których przestrzeń jest wspólna i wypełniona afektem" ${ }^{18}$. Do tego zaś potrzeba interdyscyplinarności wychodzącej poza sferę wizualną.

Współczesne studia nad kulturą wizualną stają się obszarem rozważań nad relacjami sensorycznymi, nad sposobem odczuwania, doświadczania obiektów przez ich odbiorców (celowo nie piszę tutaj o widzach), pozostając nadal kry-

12 Por. np. M. Hopfinger, Kultura audiowizualna u progu XX wieku, Instytut Badań Literackich PAN, Warszawa 1997; W. Chyła, Szkice o kulturze audiowizualnej. W stulecie ekranu w kulturze, Wydawnictwo Fundacji Humaniora, Poznań 1998; czy wiele tomów poświęconych kulturze audiowizualnej.

13 S. Sontag, Przeciw interpretacji, tłum. M. Olejniczak, „Literatura na Świecie” 1979, nr 9, s. 305.

14 Wyrażane takimi terminami jak: sensorium, telesynestezja, ucieleśnienie i in.

15 M. Bal, Jezzk afektu, tłum. M. Maryl, „Teksty Drugie” 2007, nr 1-2, s. 172.

16 Tamże, s. 183.

17 Tamże, s. 187.

18 Tamże. 
tycznym odniesieniem do relacji władzy i oporu w ramach zjawisk kultury wizualnej.

AGNIESZKA OGONOWSKA

Katedra Literatury XX wieku

Instytut Filologii Polskiej

Uniwersytet Pedagogiczny im. Komisji Edukacji Narodowej w Krakowie

Socjologia wizualna zajmuje się badaniem ikonosfery społecznej, na którą składają się wszelkie przedstawienia i przejawy wizualne. Do tych pierwszych można zaliczyć zarówno trwałe i ustabilizowane materialnie teksty kultury, jak na przykład dzieła sztuki, pocztówki, fotografie, filmy, programy telewizyjne, foldery reklamowe, wystawy sklepowe, wizualizacje architektoniczne, billboardy, tatuaże czy graffiti, jak i działania rozgrywające się w czasie rzeczywistym ich odbioru o wcześniej założonej lub przynajmniej zarysowanej strukturze (scenariuszu), na przykład przedstawienia teatralne, występy kabaretowe, performance, tańce rytualne, dzieła interaktywne, pokazy mody, ceremonie ślubne i pogrzeby, stylizacje wnętrza mieszkalnego, konferencje prasowe organizowane przez partie polityczne. Przedstawienia wizualne mogą być analizowane $\mathrm{w}$ różnych perspektywach, na przykład w kontekście instytucji odpowiedzialnych za ich produkcję i dystrybucję w systemie społecznym (na przykład galerie, kina, agencje reklamowe, biura architektoniczne), w porządku diachronicznym, na przykład odniesieniu do rozwoju różnych widowisk projekcyjnych poprzedzających rozwój kina, lub w ujęciu funkcjonalnym. Kontekst instytucjonalny (wystawienniczy) współtworzy znaczenie „gotowego” przekazu oraz wyznacza strategię jego odbioru (porównajmy choćby fotografię prezentowaną $\mathrm{w}$ galerii sztuki $\mathrm{z}$ taką, która jest umieszczona $\mathrm{w}$ albumie rodzinnym). Konkretne przedstawienie wizualne może pełnić różne funkcje jednocześnie, na przykład makijaż - ozdobną (estetyczną), tożsamościową i rytualną, lub też służyć odmiennym celom dla poszczególnych osób (na przykład pocztówka może stanowić element kolekcji lub sentymentalną pamiątkę z miejsca spędzania wakacji). Poszczególne przedstawienia w różny sposób aktywizują uczestników: raz są oni biernymi uczestnikami spektaklu (na przykład goście weselni podczas ceremonii ślubnej czy widzowie w kinie), innym razem właśnie od ich aktywności i zaangażowania zależy ukonstytuowanie się spektaklu, jak w dziełach interaktywnych. Znaczna część przekazów może być analizowana w odniesieniu do obrazu rzeczywistości, którą utrwalają lub tworzą, w zależności od przyjętej przez ich twórców filozofii reprezentacji (na przykład mimetycznej czy performatywnej). Metoda ta sprawdza się na przykład w odniesieniu do malarstwa figuratywnego, fotografii analogowej czy filmu dokumentalnego. Pytanie o reprezentatywność obrazów wobec tak zwanej rzeczywistości obiektywnej, którą reprezentują, otwiera $z$ kolei przed badaczem pole analiz ideologicznych. 
Niejednokrotnie warto zapytać, jaki system wartości został w te obrazy wpisany; czyje interesy społeczne są w ten sposób lansowane, co dzieje się w wyniku interakcji między ideologią tekstu a ideologią ich odbiorców? Co ludzie robią z tymi przekazami, niezależnie od intencji ich twórców, sponsorów, dystrybutorów, promotorów związanej z nimi ideologii? Jaki obraz rzeczywistości społecznej one legitymizują i przy wykorzystaniu jakich środków retorycznych?

Przedstawienia wizualne reprezentują także różne formy i poziomy kultury, począwszy od tych artystycznych (na przykład obrazów malarskich Rembrandta) po typowo użytkowe (na przykład reklama w galerii handlowej). Niemniej jednak w perspektywie rozwiązania konkretnego problemu badawczego, na przykład przemian ideału urody kobiecej w drugiej połowie XX wieku, socjo$\log z$ konieczności musi sięgać po wszelkie dostępne materiały ikonograficzne, które przybliżają go do poznania danej kwestii. Obiektem jego zainteresowania staną się zarówno dzieła sztuki w galeriach i muzeach, jak i żurnale mody, reklamy telewizyjne z udziałem modelek czy czasopisma erotyczne dla panów. Badacz wydobywa $z$ magazynu kultury te aspekty życia społecznego, które mogą stanowić podstawę wnioskowania odnośnie do podjętych przez niego zadań naukowych. Podstawą wartościowania tych przedstawień jest przede wszystkim ich użyteczność poznawcza (epistemologiczna). Socjolog nie tylko korzysta $z$ gotowych tekstów kultury, ale także tworzy własne przekazy wizualne, na przykład fotografie czy filmy dokumentujące badane przez niego zjawisko społeczne, lub też wykorzystuje materiały tworzone na jego prośbę przez osoby reprezentujące odmienną od niego kulturę, narodowość, orientację seksualną czy poglądy religijne.

Do przejawów wizualnych zalicza się wszystko to, co widzialne i obserwowalne oraz możliwe do wykorzystania jako źródło danych socjologicznych, na przykład zachowania społeczne w różnych konstelacjach czasoprzestrzennych, ubiór ludzi jako element komunikacji niewerbalnej, zabiegi kosmetyczne i chirurgiczne związane $z$ upiększaniem ciała, gromadzone i wyrzucane przedmioty materialne, rytuały, którym się ludzie poddają (często bezrefleksyjnie), charakter nekropolii, miejsc sakralnych, pomników przeszłości czy widocznych oznak kultów religijnych określających ich tożsamość. Istotną grupę przejawów wizualnych stanowi środowisko naturalne „naznaczone” działalnością człowieka, a także widoczne oznaki postaw ludzi wobec poszczególnych regionów naszego globu oraz ich mieszkańców. O tych ostatnich można wnioskować choćby poprzez analizę folderów biur turystycznych, kartek pocztowych, filmów dokumentujących wyprawy turystyczne lub podróżnicze (zarówno profesjonalnych, jak i amatorskich), zdjęć publikowanych w czasopismach specjalistycznych i prasie codziennej, a także fotografii przechowywanych $\mathrm{w}$ albumach prywatnych. Technologie służące utrwaleniu obrazu (od malowideł naskalnych po fotografię cyfrowa), a także sama potrzeba ich obiektywizacji i upublicznienia, towarzysząca człowiekowi przez cały jego rozwój filogenetyczny, ustanawiają niezwykle frapujące pole badań dla socjologów ukierunkowanych na studia 
diachroniczne. Pozwalają one odpowiedzieć na pytania: Czym interesowali się ludzie na przestrzeni czasu? Jak postrzegali otaczającą ich rzeczywistość? Co było dla nich najbardziej istotne? Jak wyglądał ich świat duchowy? Jakimi uczuciami darzyli Innego?

Zadaniem socjologa zajmującego się badaniem kultury wizualnej jest dostrzeganie w ikonosferze społecznej tych elementów znaczących, które mogą stać się przedmiotem szczegółowych analiz z uwagi na wcześniej postawiony problem naukowy. Ten ostatni ukierunkowuje spojrzenie badacza na dostępne mu uniwersum wizualne społeczeństwa, które może podlegać wieloperspektywicznemu oglądowi. Już liczba istniejących w dyskursie naukowym „metafor wizualnych" wskazuje nie tylko na wagę profesjonalnego spojrzenia (patrzeć nie oznacza widzieć), ale również na jego zakotwiczenie „ideologiczne” (reżimy patrzenia). Wystarczy wspomnieć takie określenia, jak: społeczeństwo nadzoru, społeczeństwo spektaklu czy społeczeństwo ekranów, by zaktualizować związany z nimi potencjał interpretacyjny, a przy okazji odświeżyć pamięć o wielu wybitnych badaczach kultury, których koncepcje mimo upływu lat (i przemian samej ikonosfery) nie tracą aktualności. Warto także zwrócić uwagę na takie zjawiska współczesności, jak: estetyzacja rzeczywistości, mediatyzacja świata, spektakularyzacja życia publicznego, fetyszyzacja obrazu, nowe przestrzenie widzialności oraz maszyn widzenia (od Panopticonu do Demopticonu), logika symulakrów oraz zjawiska ekshibicjonizmu i voyeuryzmu medialnego.

\section{KRZYSZTOF OLECHNICKI}

Zakład Badań Kultury

Instytut Socjologii

Uniwersytet Mikotaja Kopernika w Toruniu

Odpowiadając na pytania kwestionariusza bardzo chciałbym ulec pokusie udawanej niewinności i skwitować podejmowane w nim kwestie jednym zdaniem: kultura wizualna, jaka jest, każdy widzi. Niestety, tak się nie da, bo nieomal każdy widzi ją inaczej, a samo pojęcie jest tak wewnętrznie wieloaspektowe i nieprecyzyjne, uwikłane w różne konteksty i dyskusje, że aż strach się odezwać - zbliżenie się do niego wymaga nie tylko odwagi, ale i uzbrojenia się $\mathrm{w}$ pancerz tysiąca przypisów, miecz relatywizmu i tarczę autorefleksyjności. Ponadto przebijanie się przez kolejne warstwy kultury wizualnej jest o tyle syzyfowym wysiłkiem, że już elementy składowe tej koncepcji na każdego świadomego badacza działają odstraszająco. Mało kto chyba zechce dociekać, czym jest „wizualność”, a jeszcze mniej ochotników będzie chciało się dzisiaj siłować z pojęciem „kultura”, czego wszakże uniknąć się tu nie da. Co jeszcze gorsze, problemy zaczynają się od samej terminologii, ponieważ dominujące wśród polskich badaczy tłumaczenie visual culture jako „kultura wizualna” jest nie- 
ścisłe i mylące. Dlatego wolę mówić o „kulturze obrazu”, co nie uwalnia nas automatycznie od wszystkich problemów, ale przynajmniej pozwala osadzić rozważania na bardziej stabilnym gruncie. O ile bowiem w języku angielskim visual culture ma zakres szeroki, to w polskiej „kulturze wizualnej” zawęża się on na ogół do doświadczeń dostarczanych przez zmysł wzroku, co jest może nie tyle nieprawdziwe, ile raczej upraszczające, pomija obdarzony mocą nadawania znaczeń kontekst społeczno-kulturowy, który w procesie uspołeczniania programuje nasz mózg i uczy go widzenia (precyzyjniej mówiąc, jednego z nieskończonej liczby możliwych sposobów widzenia). Doświadczenia wzrokowe nie powinny być poznawczo oddzielane od innych wymiarów ludzkiego doświadczenia, gdyż fałszowałoby to istotne parametry kulturowo-społecznego środowiska człowieka, w którym wrażenia wzrokowe wchodzą zawsze w interakcje z wrażeniami dostarczanymi przez pozostałe zmysły. Sądzę, że kultura wizualna i sposoby widzenia są $\mathrm{w}$ praktyce funkcjonalną jednością i tak je też powinno się badać. Dlatego też bardzo jest mi bliska perspektywa, którą prezentuje John Berger w swoim słynnym zbiorze esejów Sposoby widzenia. Pisze on: „Obraz to widok, który został odtworzony lub zreprodukowany. Obraz to wygląd rzeczy lub zbiór wyglądów, wyrwany z pierwotnego kontekstu, w którym powstał, i utrwalony - na kilka sekund lub kilka stuleci. Każdy obraz ucieleśnia jakiś sposób widzenia" [podkr. - K.O.].

Obraz jest więc zawsze tworem ludzkim, choć przedmiot patrzenia może oczywiście być naturalny (jednak dopiero spojrzenie ludzkie, a więc wyrwanie z kontekstu i utrwalenie, czyni z unoszącego się nad wulkanem pióropusza dymu obraz $\mathrm{w}$ interesującym nas tutaj znaczeniu). Nasze widzenie jest zawsze zapośredniczone, nigdy czyste - nie przekonuje mnie podział na rzekomo niezapośredniczone „oglądanie świata” i zapośredniczone „oglądanie obrazów”. Jak przed laty pisał Mieczysław Porębski, który wprowadził pojęcie ikonosfery — utożsamianej przeze mnie z kulturą obrazu — jest to sfera, „w której rodzą się wciąż nowe obrazy wzrokowe i dźwiękowe" ${ }^{2}$, obejmująca zarówno naturę, jak i świat tworzony przez człowieka, w tym także symboliczne krajobrazy miast i wsi oraz wygląd samych ludzi. Składają się na nią „fakty pojawiania się obrazów. Wchodzą w jej zasięg obrazy bądź te, które tworzą się na naszych oczach, bądź te, które tworzyły się już wcześniej. Są wśród nich i takie - widniejące na niebie gwiazdozbiory - od których powstania dzielą nas miliony lat świetlnych. Są i te, które przed kilkunastu lub dwudziestu kilku tysiącami lat pojawiły się na ścianach prehistorycznych jaskiń, inicjując nieprzerwany ciąg twórczych poczynań myśli i wyobraźni człowieka. Są te, które niesie nam każda chwila - atakujące nas bezustannie szumy, sygnały, światła, cienie, kolory. Są wreszcie i te, o których pamiętamy, mówimy, które nie przekroczyły

\footnotetext{
${ }^{1}$ J. Berger, Sposoby widzenia, tłum. M. Bryl, Rabid, Poznań 1997, s. 9-10.

2 M. Porębski, Ikonosfera, PIW, Warszawa 1972, s. 18.
} 
jednak nigdy progu dzielącego nasz świat zewnętrzny od świata naszych snów i halucynacji" 3 .

Kultura obrazu nie powinna być zatem rozumiana statycznie, lecz dynamicznie, jako nieustający proces konstruowania ikonicznego środowiska, którego główną funkcją jest umożliwienie szeroko rozumianej symbolicznej aktywności komunikacyjnej, której artefakty i przedstawienia dostępne są dla badaczy. Kulturę obrazu badać należy, moim zdaniem, interdyscyplinarnie, w możliwie jak najszerszym spektrum wykorzystywanych orientacji teoretycznych, metod i inspiracji, ale także i „pozainterdyscyplinarnie”, przez co rozumiem wychodzenie poza świat akademickiej nauki i otwarcie na inne dyskursy i doświadczenia, na przykład artystyczne. Myślę też, że nolens volens studia nad kulturą obrazu powinny mieć charakter krytyczny, a nawet demaskatorski. Nie dlatego, że nie da się inaczej, ale dlatego, że takie są potrzeby chwili. Tak przedmioty patrzenia, jak i narzędzia służące do tworzenia obrazu pozostają obecnie pod silnym wpływem presji $z$ jednej strony polityki, a $z$ drugiej rynku i kultury konsumpcyjnej, wraz z preferowaną przez nie estetyką i etyką obrazowania. Nigdy wcześniej nasz odbiór obrazów nie był aż w takim stopniu odbiorem konsumenta $z$ wszystkimi tego konsekwencjami, a zwłaszcza z nastawieniem na ich „przyjemnościowy” charakter. Nigdy też wcześniej widzenie nie było tak silnie sprzężone $z$ pozostającymi poza naszą kontrolą technologiami obrazu. Nigdy wreszcie wcześniej obrazy nie były aż tak globalnie umasowione i nie doświadczały w konsekwencji aż takiej inflacji znaczenia.

SEAWOMIR SIKORA

Zaktad Antropologii Kulturowej

Instytut Etnologii i Antropologii Kulturowej

Uniwersytet Warszawski

Odpowiem zbiorczo. Choć „kulturę wizualną”, jako dyscyplinę, umieszcza się czasem blisko historii sztuki, to zdecydowanie słuszniejszy wydaje mi się pogląd na przykład W. J. T. Mitchella, który mówi, po pierwsze, o problematyczności w definicyjnym domknięciu tego pojęcia, które boryka się z niejednoznacznością (podobną na przykład do historii) w rozgraniczeniu między samą dyscypliną i przedmiotem jej badań; a po wtóre, uznaje tę dziedzinę raczej za nowo rodzący się fenomen interdyscyplinarny. Tak pojmowaną kulturę wizualną, jak sądzę, można by traktować jako pochodną długotrwałego procesu odchodzenia od dominacji słowa w dyskursie naukowym (i nie tylko). „Zwrot wizualny" jest terminem, który sygnalizuje ponowne zainteresowanie obrazem w jego złożoności i nieredukowalności do słowa, powiązane $\mathrm{z}$ rosnącym przekonaniem, że obrazów nie można sprowadzać do ich pozytywistycznego ujęcia

3 Tamże, s. 271. 
(literalność, referencja). Nie sądzę jednak, by ów „rozwój” był jednokierunkowy - „odklejone referencje”, diametralna zmiana, jaką miały wprowadzić fotografia cyfrowa, hipermedia i tak dalej - mniemam raczej, że obrazy dziś pojmowane są poliwalentnie, to znaczy przypisuje się im w różnych kontekstach często sprzeczne wartości i właściwości. Tym samym można mówić, paradoksalnie, zarówno o większym odcieleśnieniu obrazów, jak i przeciwnie o ich osadzeniu w zmysłowości i cielesności człowieka.

Oczywiście, kultury wizualnej nie da się sprowadzić do zajmowania się obrazem i pod tym względem, jak sądzę, szerokie jej rozumienie byłoby bliskie szerokiemu rozumieniu antropologii wizualnej, jako badania również co dość dawno zadeklarowali Banks i Morphy — funkcjonowania wizualności i systemów wizualnych $\mathrm{w}$ danej kulturze, także naszej. O tyle też, o ile antropologia wizualna zdecydowanie dziś odchodzi od badania tylko „innych kultur” i kieruje się często ku własnej (anthropology at home, homework jako swoista odmiana fieldwork), pola zainteresowań tych dyscyplin mogą się czasem (w rosnącym stopniu) pokrywać lub przynajmniej na siebie zachodzić. Nie chcę przez to powiedzieć, że antropologia wizualna ma tu pierwszeństwo, lecz jedynie, że często teorie i metody dość swobodnie fluktuują. Coraz trudniej też jasno postawić granicę między niegdyś odległymi i zdecydowanie łatwiejszymi do rozdzielenia światami (także w wymiarze czasowym: Johannes Fabian, a potem James Clifford pokazują, że długo po upadku ewolucjonizmu odmowa uznania równoczesności różnych kultur funkcjonowała mocno także $\mathrm{w}$ antropologii). Podobne rytuały można odnaleźć na Haiti i w Nowym Jorku. I choć „globalizacja" jest słowem coraz modniejszym, a różne seriale stają się fenomenem światowym, to warto dodać, że ogląda się je w różnych miejscach odmiennie. Wspólne oglądanie Dallas i dyskusje o tym pozwoliły Lili Abu-Lughod nie tylko ukazać odmienność owych spojrzeń, lecz także snuć ciekawe rozważania na temat kultury kobiet na egipskiej wsi. Długotrwałe badania terenowe, differentia specifica etnografii/antropologii, dziś stają się też czasem udziałem innych dziedzin, sam zaś nacisk na takie badania pozwala na uniknięcie uniwersalizujących spojrzeń na kulturę, odklejonych często także od „kosmosu” samego mówiącego... choć bywa i tak, że owe „terenowe prawdy” są traktowane nazbyt literalnie.

Kiedy mówiłem o interdyscyplinarności (odwołam się tu do przykładów mi bliskich), to myślałem na przykład o fenomenie ostatniej książki o fotografii Rolanda Barthesa, Camera lucida, która sama (jak i jej interpretacje) wpisuje się między innymi w dyskurs psychoanalityczny (Freud, Lacan, Winnicott), literacki i pamięciowy (między innymi Proust), ale także jest medytacją na temat śmierci (związków fotografii i śmierci) w naszej kulturze. Choć esej Barthesa trudno przypisać prozie naukowej (tu lokuje się również podejrzenie o przełamywanie konwencji i literackość, czytaj fikcyjność, samej jego książki), to warto tu przypomnieć, że rozważania na temat związku fotografii i śmierci podejmuje, i opowiada inaczej, pisarz Paul Auster w filmie Dym (1995 - 
tak przynajmniej chciałbym ów film postrzegać). Choć sam umieściłem rozważania Barthesa (i moje o nim) w obrębie antropologii wizualnej (podpowiedź Barthesa: fotografia to przedmiot antropologicznie nowy), to - jak sądzę można by je doskonale wpisać w przestrzeń kultury wizualnej. Podobnie film o roli filmowca weselnego we współczesnym środowisku małego miasteczka Żeby to byto ciekawe... (zrealizowany przeze mnie wraz z Karoliną J. Dudek, 2009) mówi o powszechnym dziś fenomenie, w którym filmowiec urasta do jednej z głównych postaci-organizatorów ślubu-wesela. Wykorzystując materiał z różnych kamer i samego filmu weselnego nie wprowadziliśmy jasnej hierarchizacji „głosów” (choć są one wydzielone). Mediacyjność owego zjawiska wiąże się dziś nie tylko $z$ wagą, jakiej nabiera wizualność, lecz także $z$ tym, że pojawiają się w nim wątki odnoszące do kultury zglobalizowanej, które mogą tam trafić zarówno via internet, jak i podpowiedziane przez sąsiada... W poszukiwaniu nowych sposobów mówienia widziałbym również namiastkę interdyscyplinarności - środek przekazu sam jest wszak przekazem...

PIOTR WOEYŃSKI*

Katedra Fotografii

Wydziat Komunikacji Multimedialnej

Akademia Sztuk Pięknych w Poznaniu

Pytania zaproponowane przez autorów ankiety początkowo wzbudziły we mnie szereg obaw. „Co to jest kultura wizualna?” brzmi równie zasadniczo jak pytanie „Co to jest sztuka?”. Gdyby pytanie to zostało skierowane do bardzo wąskiego grona specjalistów, grona posługującego się uzgodnionym rodzajem metajęzyka i na dodatek mającego ustalone, choć nie koniecznie uzgodnione, poglądy na zasadnicze kwestie występujące w reprezentowanej przez nich dziedzinie, wówczas $z$ ulgą podziękowałbym za zaproszenie i podał powody rezygnacji ze współpracy. Organizatorzy ankiety otrzymaliby prawdopodobnie zbiór odpowiedzi, które dawałyby nam wgląd w najrozmaitsze trudności; zastrzeżenia i ograniczenia, jakimi należałoby owo pytanie opatrzyć; deklaracje niemożliwości odpowiedzi na tak postawione pytanie; może propozycje przeredagowania jego brzmienia na formę, która uczyniłaby zadość wymogom danej dyscypliny. Innymi słowy, specjaliści prawdopodobnie pozostaliby na dobrze znanym sobie terenie, roztrząsając na przykładzie postawionego problemu zawiłe zagadnienia własnej dyscypliny.

Szczęśliwie organizatorzy przedsięwzięcia postąpili całkiem inaczej. Poprosili o odpowiedź osoby o najrozmaitszych profesjach, nie tylko ludzi nauki, zostawiając im przy tym swobodę co do formy wypowiedzi. Przedsięwzięcie ciekawe, ale i karkołomne. Prawdopodobnie pytań identycznie brzmiących, a za-

*Autor nadał swojej wypowiedzi tytuł „O uwalnianiu obrazów z niewoli patrzenia” (przyp.red.). 
wierających zupełnie odmienne treści: „Co to jest kultura wizualna?”, będzie tyle, ilu uczestników ankiety. Prawdopodobnie każdy z nas, uczestniczących w ankiecie, będzie dawał odpowiedź na inne, choć tak samo brzmiące pytanie. Sytucja ta wydaje mi się bardzo dogodna, pozwala bez szczegółowego usprawiedliwiania przeredagować propozycje autorów ankiety. Nakierować w ten sposób uwagę czytelnika na własny sposób rozumienia postawionego zagadnienia, i w nim podjąć problemy, które wydają się najważniejsze.

Moje „pytanie pomocnicze” jest związane z fotografią lub, szerzej, rejestracją obrazu; dziedziną, którą zajmuję się przede wszystkim jako praktyk. Brzmi ono następująco: Jaka jest rola mechanicznych narzędzi rejestracji obrazu w nadawaniu kształtu kulturze wizualnej?

Fakt, że kultura wizualna zdominowana jest od dawna wytworami narzędzi rejestrujących: obrazem fotograficznym, filmem, później innymi formami zapisu ruchomego obrazu, jest oczywisty. Najczęściej nie zwracamy uwagi na wszystkie konsekwencje tego faktu. Otóż od momentu ich pojawienia się w kulturze otrzymaliśmy do dyspozycji obrazy o zupełnie nowych cechach. Najważniejszą z nich jest uwolnienie się obrazu z niewoli widzenia.

Otrzymaliśmy do dyspozycji obrazy, które trudno bez poważnych zastrzeżeń włączyć w obszar tradycji dotychczasowego obrazowania. Takie próby (na przykład piktorializm) oczywiście były i są do tej pory podejmowane. Nie mają jednak większego wpływu na współczesną ikonosferę. Efektownie przedstawił tę sytuację Jean Baudrillard, nazywając fotografię „obrazem dzikim”, trudnym do wpisania w dotychczasową historię sztuki. „Obraz fotograficzny [...] rodzi się $z$ istoty własnej techniki i właśnie dlatego stanowi wielką rewolucję w naszym sposobie przedstawiania. [...] Stąd forma dzika, nie dająca się sprowadzić do estetyzacji rzeczy, związana $z$ ich zewnętrznym wyglądem, $z$ ich oczywistością, ale oczywistością złudną. Całkowicie przeciwna podwójnemu przeznaczeniu, jakie jej narzucono: realizmowi i estetyzmowi" ${ }^{1}$. Od momentu zdominowania wytwarzania obrazów przez mechaniczne środki rejestracji obszar widzialności i obszar obrazowania są względnie autonomiczne. Oczywiście tradycyjne wzory kulturowe początkowo utrudniają dostrzeżenie tego zjawiska, fotografia jest doceniana przede wszystkim za to, że potwierdza to, co widzimy. Uświadomienie sobie rewolucyjnej roli mechanicznych środków rejestracji odbywa się najpierw w dwóch odmiennych dziedzinach: nauce i sztuce.

Przedstawiciele tych dwóch dziedzin uświadamiają sobie dość szybko, że epokowe konsekwencje wynalazku mechanicznej rejestracji obrazu tkwią w tym, że między widzeniem (ze wszystkimi jego uwarunkowaniami) a obrazem mechanicznym istnieje kolosalna różnica, i że to właśnie owa różnica jest najistotniejsza. Do tego czasu naturalne doświadczenie wytwarzało w miarę spójny obraz świata, teraz przestał on obowiązywać, stracił swoją legitymację.

\footnotetext{
${ }^{1}$ J. Baudrillard, Przed końcem. Rozmawia Philippe Petit, tłum. R. Lis, Sic!, Warszawa 2001, s. 118.
} 
Jaka jest zatem rola narzędzi rejestracji obrazu w tworzeniu kultury wizualnej? Wytworzone mechanicznie obrazy wprowadzają w obszar kultury wartość całkowicie odmienną, bo nie opartą na zasadach mimetyzmu. Choć w społecznym odbiorze są kontynuatorem dawnego obrazowania, to ich energia skoncentrowana jest na wytwarzaniu nowego (medialnego) typu rzeczywistości. Trafnie ujął to André Rouillé: „Dogmat odcisku skrywa przed nami fakt, że fotografia, podobnie jak dyskurs i inne obrazy, tworzy byt; będąc w całości konstrukcją, tworzy i powołuje do życia inne światy" 2 . W konsekwencji współczesną kulturę wizualną należy traktować jako zjawisko całkowicie odrębne, ustanawiające nowe zasady rozumienia tego, co dostarczają zmysły.

Powstaje pytanie, czy coś kryje się jeszcze za obrazami? Pogląd, że jednak nie, zyskuje coraz większą popularność. Sztuki wizualne natomiast mogą być postrzegane jako dziedzina, w której obrębie powstają nowe modele oswajania, humanizowania obrazów. Jej aktywność prowadzi do nadawania obrazom sensu, który zupełnie pomija problem odniesienia, nie limitując przy tym zasięgu swojej problematyki. To paradoks, który dobrze uzmysławia charakter współczesnej sztuki. Sztuka może dziś być wszystkim i mówić o wszystkim, właśnie dlatego że jest tylko sobą i mówi tylko w swoim imieniu. Powstające w ten sposób nowe modele oswajania i humanizowania obrazów rozprzestrzeniają się na cały obszar nazywany kulturą wizualną, zmieniając jej charakter. Wpływ na jej kształt ma, oczywiście, nie tylko sztuka (choć tutaj należałoby dopatrywać się jednego z ważniejszych czynników), ale także wiele dziedzin aktywności ludzkiej.

Ważne, że prawdopodobnie one wszystkie w podobny sposób wpływają na to, że kultura wizualna $\mathrm{w}$ coraz większym stopniu powstaje $\mathrm{w}$ wyniku modelowania zjawisk według zasad wywodzących się z najnowszych technologii. Obrazowanie multimedialne, szybko i skutecznie zmieniające lub zastępujące omawiane środki rejestracji, przyczynia się do dalszego uwolnienia obrazów $z$ niewoli widzenia.

\section{STUDIES OF VISUALITY IN A MULTIDISCIPLINARY PERSPECTIVE VISUAL CULTURE QUESTIONNAIRE}

\section{Summary}

The Kwestionariusz Kultury Wizualnej (Polish Visual Culture Questionnaire) is a nation-wide scientific project. Over forty Polish researchers and artists, representing the fields of sociology, anthropology, cultural studies, film studies, philosophy, photography, media studies and art history, were asked to answer two questions: what is visual culture?; whether it is worthy of study and how and why? This article contains the project's assumptions and answers to the above questions.

\footnotetext{
2 A. Rouillé, Fotografia. Między dokumentem a sztuka wspótczesna, tłum. O. Hedemann, Universitas, Kraków 2007, s. 10-11.
} 


\section{Key words/słowa kluczowe}

Visual Culture Questionnaire / Kwestionariusz Kultury Wizualnej; photography / fotografia; ways of seeing / sposoby patrzenia; visual sociology / socjologia wizualna; eye-based interactions / okocentryczne interakcje 